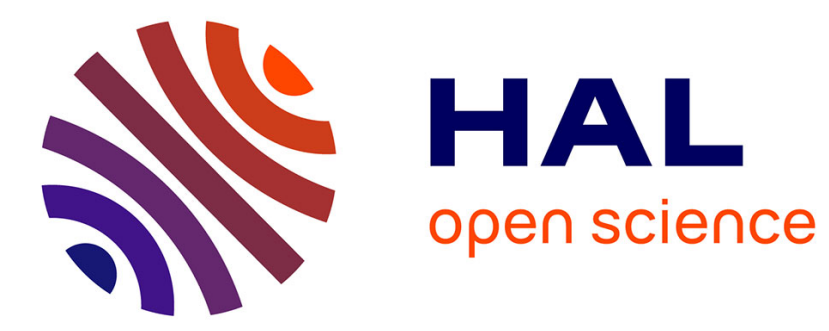

\title{
Crustal origin of Early Proterozoic syenites in the Congo Craton (Ntem Complex), South Cameroon
}

\author{
Rigobert Tchameni, K. Mezger, N. E. Nsifa, André Pouclet
}

\section{To cite this version:}

Rigobert Tchameni, K. Mezger, N. E. Nsifa, André Pouclet. Crustal origin of Early Proterozoic syenites in the Congo Craton (Ntem Complex), South Cameroon. Lithos, 2001, 57, pp.23-42. 10.1016/S0024-4937(00)00072-4. hal-00089823

\section{HAL Id: hal-00089823}

\section{https://hal-insu.archives-ouvertes.fr/hal-00089823}

Submitted on 26 Nov 2007

HAL is a multi-disciplinary open access archive for the deposit and dissemination of scientific research documents, whether they are published or not. The documents may come from teaching and research institutions in France or abroad, or from public or private research centers.
L'archive ouverte pluridisciplinaire HAL, est destinée au dépôt et à la diffusion de documents scientifiques de niveau recherche, publiés ou non, émanant des établissements d'enseignement et de recherche français ou étrangers, des laboratoires publics ou privés. 


\title{
Crustal origin of Early Proterozoic syenites in the Congo Craton (Ntem Complex), South Cameroon
}

\author{
R. Tchameni ${ }^{1, a, b}$, K. Mezger ${ }^{b, c}$, N. E. Nsifa ${ }^{a}$ and A. Pouclet ${ }^{d}$ \\ ${ }^{a}$ Département des Sciences de la Terre, Université de Yaoundé I, B.P. 812, Yaoundé, \\ Cameroon \\ ${ }^{\mathrm{b}}$ Max-Planck-Institut für Chemie, Postfach 3060, D-55020 Mainz, Germany \\ ${ }^{\mathrm{c}}$ Institut für Mineralogie, Zentrallabor für Geochronologie, Universität Münster, Corrensstr. \\ 24, D-48149 Münster, Germany \\ d Département des Sciences de la Terre et UMR 6530, UFR Sciences, Université d'Orléans, \\ B.P. 6759, 45067 Orléans Cedex 2, France
}

\section{Abstract}

Two petrographically different syenite suites can be distinguished in the mostly Archean Ntem Complex of Cameroon: a suite of two-pyroxene syenites and a suite of clinopyroxene syenites. The syenites occur as discrete intrusions surrounded by Archean gneisses. Based on structural relationships the syenites are of late to post-orogenic origin. $\mathrm{The} \mathrm{Pb}-\mathrm{Pb}$ zircon evaporation ages indicate that the syenites intruded at ca. $2.3 \mathrm{Ga}$ and thus postdate significantly the Archean episode of crust formation and differentiation that generated the surrounding gneiss terrane.

The isotope signatures and the trace elements provide unambiguous evidence that the two syenite suites are of crustal origin. The syenite suites do not show simple chemical trends, have highly variable trace element contents and display only a small variation in their major element contents, particularly in their $\mathrm{SiO}_{2}$ contents. The isotope characteristics, including ${ }^{143} \mathrm{Nd} /{ }^{144} \mathrm{Nd},{ }^{87} \mathrm{Sr} /{ }^{86} \mathrm{Sr}$ and common $\mathrm{Pb}$, point to a heterogeneous source or multiple sources for the syenites. The $\mathrm{Sr}$ isotope compositions calculated for the time of intrusion vary over a wide range from an unrealistically low ${ }^{87} \mathrm{Sr} /{ }^{86} \mathrm{Sr}$ ratio of 0.690 to high values of 0.713 . In contrast the initial ${ }^{143} \mathrm{Nd} /{ }^{144} \mathrm{Nd}$ ratios are more homogenous with $\mathrm{eNd}_{(2320)}$ from -5.8 to -7.5 . The $\mathrm{Pb}$ isotopes from leached $\mathrm{K}$-feldspars indicate that the sources of the syenites had a history of $\mathrm{U}$ depletion and $\mathrm{Th} / \mathrm{U}$ enrichment.

The syenites show the same isotope characteristics as the surrounding gneiss terrane, thus the deep continental crust of the Ntem Complex itself is the most likely source for the syenite melts. This conclusion is also supported by the heterogeneity of the trace elements in the syenites that exclude a homogenous source. In addition, inherited zircons from the syenites yield $\mathrm{Pb}-\mathrm{Pb}$ evaporation ages that are consistent with ages obtained for zircons extracted from the surrounding gneisses. In contrast to many other syenites worldwide, the syenites in the Ntem Complex do not contain juvenile mantle material, but are the sole products of crustal reworking. Thus, the syenites did not contribute to the crustal growth in the Ntem Complex. However, this conclusion may not preclude the possibility that the syenites were generated in the deep crust during a time of addition of mantle material to the continental crust. The cause for the generation of these large syenite bodies in the Ntem Complex is most likely an episode of deep-seated thermal activity that was so far not known from this part of the Congo Craton.

Author Keywords: Early Protezoic; Syenites; Congo Craton 


\section{Introduction}

Despite their relative scarcity, alkaline intrusions have attracted much attention from petrologists and geochemists alike. The reasons for this are their unusual mineral assemblages and extreme enrichment in certain elements that can even lead to economic deposits of rare elements. The major geochemical reason to study these rocks is the information they hold with respect to enrichment and differentiation processes in the crust and mantle. Numerous alkaline intrusions have been studied, but their genesis is still quite obscure and open for debate, and there may be several mechanisms that lead to the formation of such magmatic rocks. Alkaline magmatism is known from all geologic ages but seems to be quite rare in the Archean and Early Proterozoic compared with Late Proterozoic and Phanerozoic times (e.g., Peccerillo; $\mathrm{M}$ and Blichert).

The term "alkaline rocks" refers to rocks that contain modal or normative feldspathoids or other minerals whose presence indicates that the rocks have high concentrations of alkalis, generally more than can be accommodated by feldspars alone (Fitton and Upton, 1987). The excess in alkalis leads to the presence of feldspathoids, sodic pyroxenes, sodic amphiboles and other alkali-rich phases. Based on the tectonic setting of their occurrence, the alkaline magmas may be subdivided into three main groups: (a) continental rift and intraplate magmas, (b) oceanic intraplate magmas, and (c) alkaline magmas related to subduction processes (i.e., the shoshonitic association of oceanic and continental island arcs). Modern alkaline rocks associated with each of these settings show distinct isotopic compositions and incompatible trace element concentrations. These characteristics could potentially be applied to Precambrian alkaline rocks in order to decipher the nature of the tectonic regime early in Earth's evolution (e.g., Müller et al., 1992).

One group of alkaline rocks that occurs worldwide in different parts of the continental crust are syenites. These are intrusive rocks dominantly made up of K-feldspar and quartz but may also contain feldspathoids, particularly nepheline. The mafic minerals can include biotite, pyroxenes and amphiboles. The origin of syenites is still not well understood. Models proposed for their generation include crystal fractionation of alkali or transitional basaltic magma, combined with varying degrees of crustal assimilation (e.g., Fitton; Nielsen and Downes), or small-degree partial melting of enriched upper mantle or lower crust Harris; Woolley; Bailey; Smith and Zanvilevich). Large intrusions of syenites are restricted to the continental crust. This limited occurrence may be taken as evidence that syenites are not primary mantle melts and the crust plays some role in their genesis either as source, contaminant or place of fractionation.

Most Archean to Early Proterozoic rocks have undergone some sort of later modification and their trace elements and isotope systematics may be disturbed. These later geologic overprints often obscure the processes involved in the petrogenesis of old rocks. However, syenites are quite robust to later alteration and modification of their trace element budget, because the elements and isotopes of interest (alkalis, $\mathrm{Sr}$, rare earth element (REE), $\mathrm{Pb}$ ) are present in very high concentrations. Thus, syenites are ideally suited for isotope studies related to early crustal genesis. Although Archean and early Proterozoic syenites are extremely rare, postkinematic syenites are widespread in the mostly Archean Ntem Complex in Southern Cameroon.

Syenites of different ages have been reported in a number of locations in Southern Cameroon: (1) Pan-African nepheline syenites in the Rocher de Loup area and at Mont des Elephants 
south of Kribi town near the Atlantic coast (Kornprobst; Nsifa and Toteu), (2) Early Proterozoic clinopyroxene syenites in the Doum-Lolodorf area (Edimo, 1985), and (3) Early Proterozoic two-pyroxene syenites in the area west of Mengueme (Tchameni, 1997). The origin and geotectonic significance of all these occurrences is not yet understood. In this study, a detailed geochemical and isotopic investigation is presented for the Early Proterozoic syenites in the Doum-Lolodorf and Mengueme areas (Fig. 1 and Fig. 2). Both occurrences are part of the mostly Archean Ntem Complex.

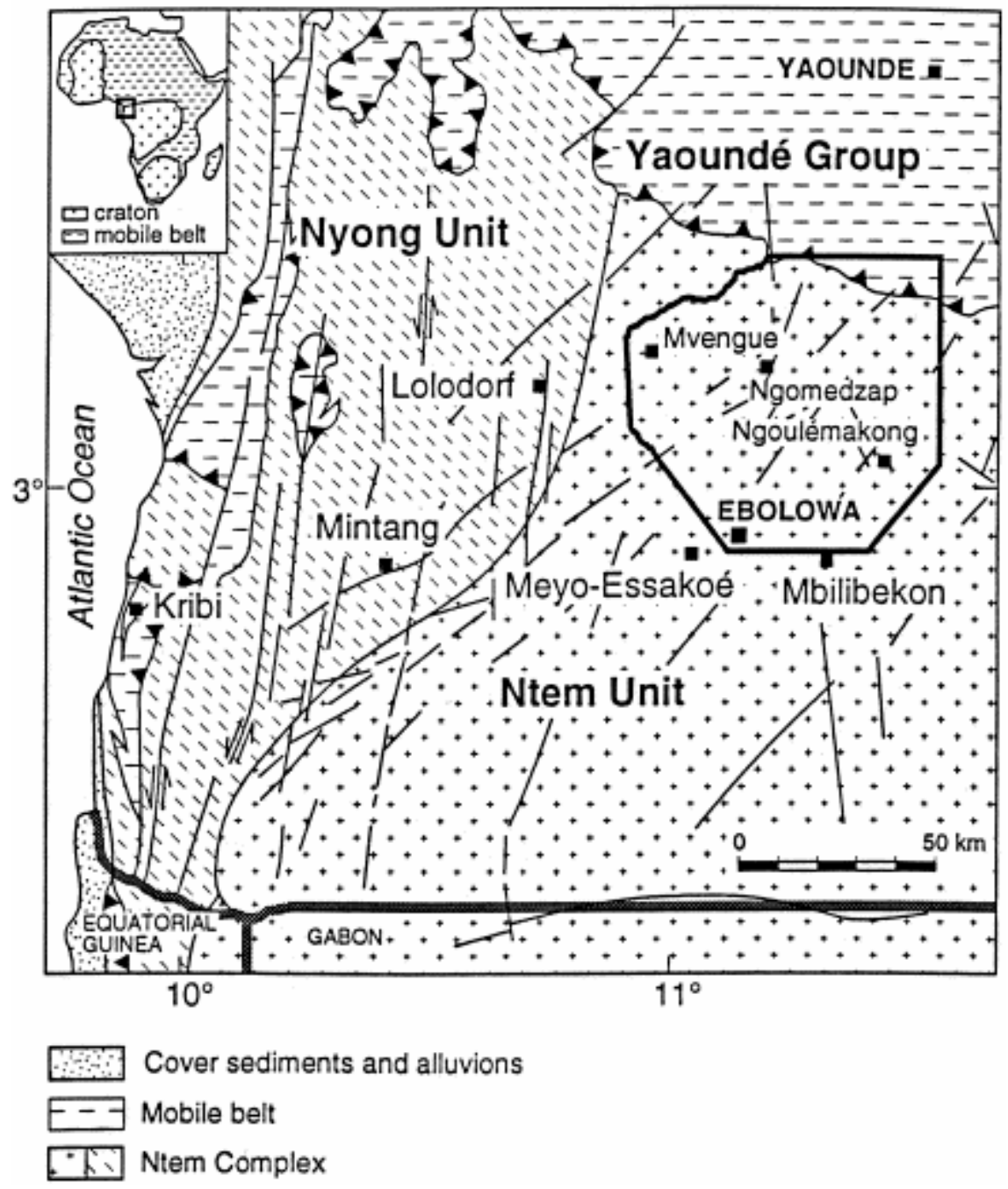

Fig. 1. Schematic map of Ntem Complex showing the location of the Ebolowa area along the NW margin of the Archean Congo Craton. The Ntem Complex consists of the Ntem and Nyong Units.

\section{Geological setting}

The Ntem Complex constitutes the northwestern part of the Congo Craton and is very well exposed in Southern Cameroon (Maurizot et al., 1985 and Goodwin; Fig. 1). The complex is made up dominantly of Archean rocks with some reworked material that formed in Early Proterozoic times (Tchameni, 1997). The western part of the Ntem Complex is made up of the Ntem and Nyong Units (Fig. 1). It is composed of different lithological groups including Archean greenstone belts, now only preserved as xenoliths of variable size in the younger intrusive complexes (Nsifa and Tchameni, 1997). These intrusive complexes are represented 
by the tonalitic, trondhjemitic and granodioritic (TTG) suite of rocks dated by mineral and whole rock techniques to have formed between 2.9 and $2.8 \mathrm{Ga}$ (Delhal; Lasserre; Cahen; Toteu; Tchameni and Tchameni). Strong deformation of the rocks from the greenstone belts and late Archean high K-granitoids led to the formation of a strong gneiss fabric (Maurizot et al., 1985; Nsifa; N; Tchameni, 1997 and Tchameni). The syenites cross-cut the greenstone belts and the members of TTG suite and thus postdate the major crust forming events (Kornprobst et al., 1976). The structurally youngest rocks are two distinct generations of metadolerites of Paleoproterzoic (=Eburnean) age (Toteu and Vicat) that form veins crosscutting structures of all the older formations.

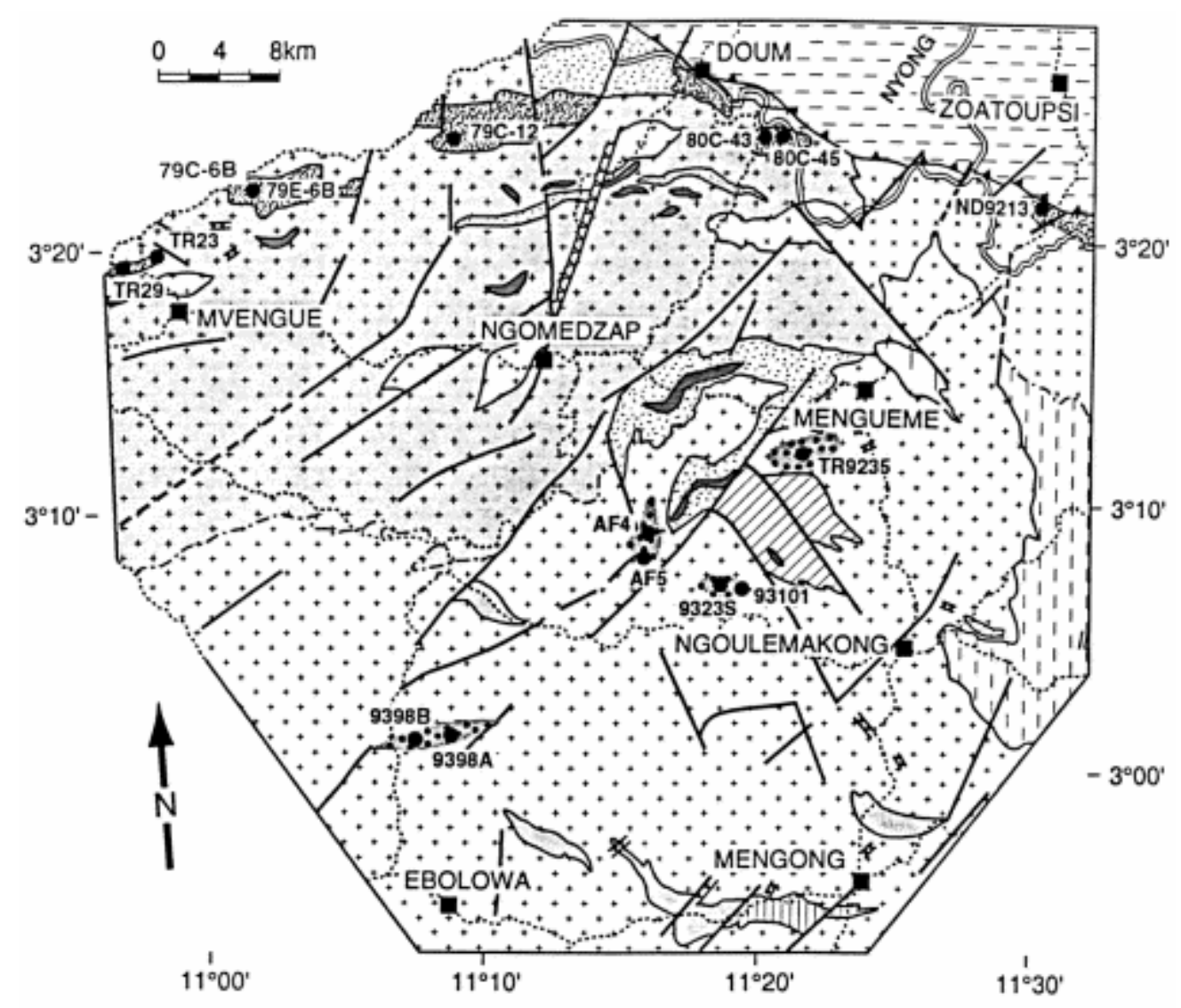

Legend:
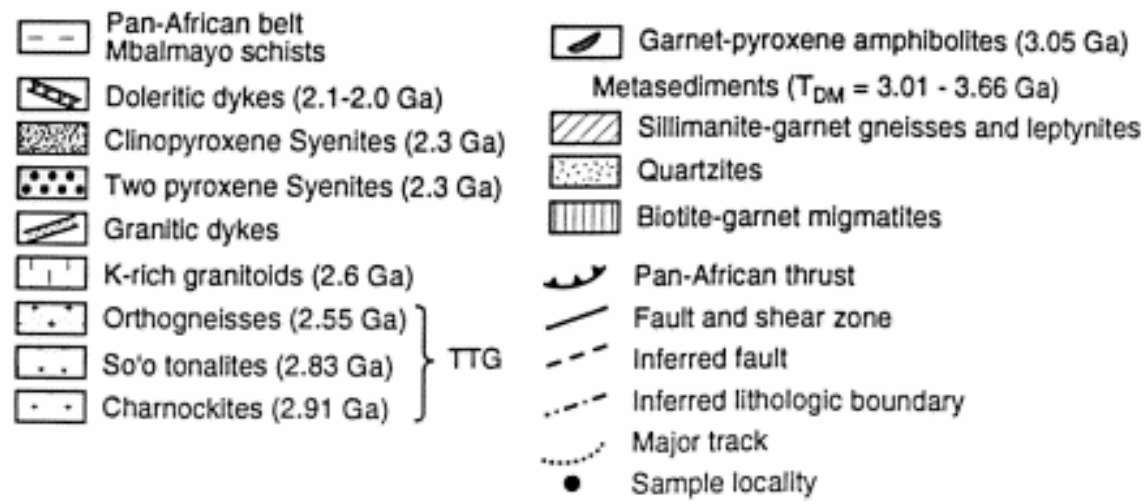

Fig. 2. Geological map of the Ebolowa area showing the location of the clinopyroxene and two-pyroxene syenites and surrounding gneisses. The ages given for the individual geologic units are taken from the summary in Tchameni (1997). Numbers refer to samples discussed in the text. 
The Archean terranes in the Ntem Complex are dominated by dome and basin tectonics related to diapiric movements in the mid to lower crust. The entire complex appears to have been coaxially strained (Tchameni, 1997). The vertical $\mathrm{S}_{1}$ foliation, oriented $\mathrm{N} 80$ to $\mathrm{N} 120^{\circ} \mathrm{E}$, is observed in the relict greenstone belts and the TTG series. A N-S orientation of $\mathrm{S}_{1}$ is locally found, especially in the K-rich granitoids and the tonalites (Fig. 2). Emplacement of the charnockitic rocks of the TTG series is synchronous with granulite facies metamorphism $\left(750 \pm 50^{\circ} \mathrm{C} ; 5-6 \mathrm{~kb}\right)$. Some authors interpret dome and basin structures as a result of the development of gravitational instabilities (Brun; Collins; Bouhalier and Choukroune). This process, termed sagduction, has been applied to several Archean cratons (e.g., Anhaeusser and Drury). This Archean episode of deformation was followed in the Paleoproterozoic by transcurrent deformation marked by an $\mathrm{S}_{2}$ foliation and $\mathrm{C}_{2}$ sinistral shear-planes oriented $\mathrm{N}-\mathrm{S}$ to $\mathrm{N} 50^{\circ} \mathrm{E}$. The syenites intruded during this second tectonic episode. The Eburnean metamorphism, which affected all the older formations and the syenites, was dated at $2.05 \mathrm{Ga}$ using the U-Pb systematics of zircons (Toteu et al., 1994).

Based on the field occurrence (geographical localities) and petrography, two groups of syenites can be clearly distinguished in the Ntem complex: (1) two-pyroxene syenites that intruded the Archean charnockites and are exposed as NE-SW striking bodies near Mengueme north of the town of Ebolowa; (2) clinopyroxene syenites in the Doum-Lolodorf area (Fig. 1 and Fig. 2). These clinopyroxene-syenites consist of numerous intrusions that form a NE-SW oriented elongated composite intrusive body that runs for nearly $70 \mathrm{~km}$ (Edimo, 1985) and follows a tectonic zone across the Ntem Complex from the Nyong river near Doum to Lolodorf town in the SW. Individual syenite intrusions form elongated bodies that are up to $20 \mathrm{~km}$ long and $4 \mathrm{~km}$ wide (Fig. 2) and thus represent an important rock type in the Ntem Complex. In both localities, the syenites and their country rocks are intruded by late metadolerite dikes.

\section{Analytical techniques}

Major and trace elements (Table 1) were analyzed at the Johannes-Gutenberg-Universität, Mainz, by X-ray fluorescence spectrometry and the CRPG at Nancy by ICP and ICP-MS. The REEs were determined at St. Johns University (Newfoundland, Canada) (samples ND9213, TR9235, 9398A) and at the CRPG in Nancy (rest of the samples) by ICP-MS. Sr, Nd and Sm were analyzed at the Max-Planck-Institut für Chemie in Mainz. The details of the chemical procedure used to separate $\mathrm{Sr}, \mathrm{Nd}$ and $\mathrm{Sm}$ are described in White and Patchett (1984). For analysis, $\mathrm{Sm}$ and $\mathrm{Nd}$ were loaded separately on Re-Re double filaments and run as metal. $\mathrm{Sr}$ was loaded with $\mathrm{TaF}_{5}$ on Re-single filaments. All analyses were performed on a Finingan MAT261 mass spectrometer at the Max-Planck-Institut für Chemie in Mainz. All Nd isotope ratios were normalized to ${ }^{146} \mathrm{Nd} /{ }^{144} \mathrm{Nd}=0.7219$, and all $\mathrm{Sr}$ isotope ratios to ${ }^{86} \mathrm{Sr} /{ }^{88} \mathrm{Sr}=0.1190$. During the course of this work, mean values for ${ }^{143} \mathrm{Nd} /{ }^{144} \mathrm{Nd}$ ratios obtained for the La Jolla and ${ }^{87} \mathrm{Sr} /{ }^{86} \mathrm{Sr}$ ratios obtained for NBS-SRM-987 standards were $0.511841 \pm 16(2 \sigma)$ and $0.71026 \pm 18(2 \sigma)$. The $2 \sigma$ errors given in Table 4 and Table 5 represent within-run precision. Model ages were calculated using values of present-day depleted mantle defined by Goldstein et al. (1984): ${ }^{143} \mathrm{Nd} /{ }^{144} \mathrm{Nd}=0.51316$ and ${ }^{147} \mathrm{Sm} /{ }^{144} \mathrm{Nd}=0.21357$. Decay constants were taken from Steiger and Jäger (1977) and Lugmair and Marti (1978). The Pb ratios of syenites are determined on acid leached K-feldspar following the technique described in DeWolf and Mezger (1994). The $\mathrm{Pb}$ isotopes are corrected for fractionation using a factor of $0.1 \%$ per AMU based on multiple analyses of the NBS SRM 982 standard. 
Table 1. Major and trace element compositions of the alkaline syenites

\begin{tabular}{|c|c|c|c|c|c|c|c|c|c|c|c|c|c|c|}
\hline \multirow[t]{2}{*}{ Samples } & \multicolumn{7}{|c|}{ Clinopyroxene syenites } & \multicolumn{7}{|c|}{ Two-pyroxene syenites } \\
\hline & $80 \mathrm{C} 45$ & TR23 & $79 \mathrm{C} 32$ & TR29 & $80 \mathrm{C} 43$ & $79 \mathrm{E} 6 \mathrm{~B}$ & $79 \mathrm{C} 12$ & $\mathrm{AF} 4$ & 93101 & AF7 & $9323 \mathrm{~S}$ & ND9213 & TR9235 & $9398 \mathrm{~A}$ \\
\hline $\mathrm{SiO}_{2}$ & 57.02 & 57.64 & 59.18 & 58.62 & 59.43 & 60.22 & 61.26 & 54.87 & 55.25 & 57.40 & 59.02 & 59.15 & 59.33 & 61.89 \\
\hline $\mathrm{Al}_{2} \mathrm{O}_{3}$ & 12.23 & 14.86 & 14.584 & 14.51 & 14.57 & 16.23 & 16.51 & 17.01 & 17.45 & 16.30 & 16.20 & 16.66 & 19.03 & 17.55 \\
\hline $\mathrm{Fe}_{2} \mathrm{O}_{3} \mathrm{t}$ & 7.18 & 4.41 & 7.58 & 6.51 & 5.62 & 4.78 & 3.99 & 6.26 & 8.24 & 6.17 & 5.19 & 3.7 & 4.29 & 2.12 \\
\hline $\mathrm{MnO}$ & 0.15 & 0.11 & 0.12 & 0.11 & 0.13 & 0.09 & 0.11 & 0.10 & 0.13 & 0.06 & 0.08 & 0.1 & 0.07 & 0.09 \\
\hline $\mathrm{MgO}$ & 2.29 & 3.10 & 1.60 & 2.80 & 1.40 & 2.13 & 1.46 & 1.82 & 1.89 & 2.05 & 2.07 & 3.08 & 1.88 & 0.97 \\
\hline $\mathrm{CaO}$ & 7.74 & 7.01 & 3.78 & 5.24 & 4.50 & 3.37 & 2.77 & 6.02 & 5.54 & 6.07 & 4.14 & 8.48 & 5.18 & 3.37 \\
\hline $\mathrm{Na}_{2} \mathrm{O}$ & 2.80 & 4.60 & 4.41 & 3.85 & 2.53 & 4.56 & 4.87 & 4.61 & 4.03 & 4.28 & 4.27 & 6.28 & 5.93 & 4.60 \\
\hline $\mathrm{K}_{2} \mathrm{O}$ & 6.81 & 6.12 & 7.47 & 6.23 & 9.61 & 6.31 & 6.79 & 5.97 & 4.70 & 5.19 & 6.26 & 0.92 & 3.12 & 6.48 \\
\hline $\mathrm{TiO}_{2}$ & 0.18 & 0.64 & 0.52 & 0.46 & 0.28 & 0.41 & 0.40 & 0.97 & 0.93 & 0.70 & 0.90 & 0.72 & 0.27 & 0.42 \\
\hline $\mathrm{P}_{2} \mathrm{O}_{5}$ & 1.19 & 1.13 & 0.46 & 0.75 & 0.30 & 0.46 & 0.33 & 0.97 & 0.76 & 1.07 & 0.66 & 0.25 & 0.27 & 0.21 \\
\hline LOI & 1.03 & 0.65 & 0.25 & 0.89 & 0.81 & 0.84 & 0.76 & 1.06 & 1.20 & 0.87 & 0.96 & 0.80 & 0.95 & 1.20 \\
\hline Total & 98.62 & 100.27 & 99.95 & 99.97 & 99.18 & 99.40 & 99.25 & 99.66 & 100.12 & 100.16 & 99.75 & 100.14 & 100.32 & 98.90 \\
\hline $\begin{array}{l}\mathrm{Na}_{2} \mathrm{O}+ \\
\mathrm{K}_{2} \mathrm{O}\end{array}$ & 9.61 & 10.72 & 11.88 & 10.08 & 12.14 & 10.87 & 11.66 & 10.58 & 8.73 & 9.47 & 10.53 & 7.20 & 9.05 & 11.08 \\
\hline $\begin{array}{l}\mathrm{K}_{2} \mathrm{O} / \\
\mathrm{Na}_{2} \mathrm{O}\end{array}$ & 2.43 & 1.33 & 1.75 & 1.62 & 3.80 & 1.38 & 1.39 & 1.30 & 1.17 & 1.21 & 1.47 & 0.15 & 0.53 & 1.41 \\
\hline $\mathrm{Mg} \#$ & 0.42 & 0.61 & 0.32 & 0.49 & 0.36 & 0.50 & 0.45 & 0.39 & 0.34 & 0.43 & 0.47 & 0.65 & 0.49 & 0.51 \\
\hline V & 91 & 82 & 89 & 81 & 145 & 77 & 47 & 138 & 124 & 64 & 102 & 34 & 63 & 32 \\
\hline $\mathrm{Cr}$ & 5 & 18 & 78 & 40 & 34 & 97 & 72 & 39 & 16 & 44 & 49 & 16 & 30 & 0 \\
\hline Co & 9 & 7 & 12 & 10 & 7 & 9 & 8 & 12 & 15 & 9 & 14 & 10 & 8 & 6 \\
\hline $\mathrm{Ni}$ & 45 & 47 & 18 & 25 & 48 & 48 & 28 & 32 & 25 & 20 & 21 & 13 & 23 & 5 \\
\hline $\mathrm{Cu}$ & 43 & 36 & 28 & 139 & 109 & 26 & 15 & 17 & 206 & 10 & 11 & 2 & 12 & 6 \\
\hline $\mathrm{Zn}$ & 105 & 86 & 118 & 84 & 74 & 73 & 62 & 82 & 73 & 77 & 94 & 50 & 45 & 70 \\
\hline $\mathrm{Ga}$ & & 15.3 & 18.3 & 16.5 & & & & 18 & 19.8 & 23 & 22 & 17.8 & 19.4 & 16.8 \\
\hline $\mathrm{Rb}$ & 153 & 150 & 264 & 179 & 204 & 143 & 110 & 67 & 160 & 89 & 100 & 7 & 52 & 68 \\
\hline $\mathrm{Sr}$ & 1383 & 1200 & 1650 & 1244 & 925 & 1531 & 1690 & 939 & 716 & 785 & 716 & 875 & 1486 & 3989 \\
\hline $\mathrm{Y}$ & 51 & 32 & 20 & 30 & 28 & 23 & 27 & 34 & 23 & 30 & 32 & 27 & 12 & 32 \\
\hline $\mathrm{Hf}$ & & & & & & & & & & & & 1.02 & 3.05 & 3.33 \\
\hline $\mathrm{Zr}$ & 93 & 71 & 250 & 261 & 350 & 232 & 140 & 118 & 212 & 206 & 189 & 31 & 88 & 168 \\
\hline $\mathrm{Ta}$ & & & 0.23 & & & & & & & & & 0.7 & 0.24 & 1.42 \\
\hline $\mathrm{Nb}$ & 7 & 13 & 2 & 7 & 17 & 8 & 6 & 10 & 13 & 8 & 12 & 26 & 5 & 32 \\
\hline $\mathrm{Ba}$ & 5435 & 2900 & 4463 & 3737 & 5368 & 3047 & 3985 & 2298 & 1491 & 1832 & 1984 & 869 & 2101 & 5000 \\
\hline $\mathrm{Pb}$ & & 12.3 & 9.5 & 21.7 & & & & 35 & 28 & 38 & 52 & 7.9 & 20.8 & 19.1 \\
\hline Th & & 4.56 & 3 & 4.4 & & & & 14 & 9.2 & 13 & 17 & 6.2 & 4.1 & 27.7 \\
\hline $\mathrm{U}$ & & 1.6 & 0 & & & & & 3 & 1.5 & 4 & 5 & & 0.8 & 1.2 \\
\hline
\end{tabular}

The $\mathrm{Pb}-\mathrm{Pb}$ ages were obtained zircon using the single grain evaporation method described by Kober and Kober. The zircons were separated from the whole samples following standard mineral separation techniques (crushing, heavy liquids, magnetic separator) and final hand picking under a binocular microscope. For analysis, clear zircons with magmatic habit and without visible cores were selected. The details of the technique used for the samples in this study are described in Kröner and Hegner (1998). All isotope and regression calculation were done using the program Isoplot/Ex version 2.01 of Ludwig (1999).

\section{Petrography of the syenites}

The two-pyroxene syenites and the clinopyroxene syenites from the Ntem complex were first described by Edimo (1985) and Tchameni, 1989 and Tchameni, 1997. The two-pyroxene syenites consist mainly of salite or ferrosalite, hypersthene, plagioclase (An 4-15\%) and abundant perthitic K-feldspar. Some samples have small amounts of quartz and biotite. Actinolite occurs as small patches along the rims of pyroxene, indicating that it is of secondary origin. Accessory apatite, titanite and zircon are common. Opaque minerals are mainly ilmenite and magnetite. In very rare cases trace amounts of garnet were observed. Textural features clearly indicate that garnets in most of the clinopyroxene syenites are of metamorphic origin. Clinopyroxene syenites are the most abundant syenites in southern Cameroon. In outcrop they appear heterogeneous in terms of mineral assemblage, modal 
composition and texture. They are medium- to coarse-grained and range from melano-syenite to leuco-syenites. Melanocratic and leucocratic layers alternate rhythmically in many outcrops and can be several tens of meters thick. The mafic syenites are predominantly composed of diopside-hedenbergite $\mathrm{Cpx}$ series and perthitic alkali feldspar with minor amounts of amphibole, biotite, sodic plagioclase (An 8-20\%) and accessory titanite, apatit, ilmenite and magnetite. Secondary phases are chlorite, biotite, actinolite, albite, calcite and magnetite. The felsic clinopyroxene syenites consist primarily of perthitic alkali feldspar and lesser amounts of salite. The sodic plagioclase usually occurs as patches or veins in perthite or as small blebs along the grain boundaries of $\mathrm{K}$-feldspar. This is strong evidence that originally only a single feldspar was present and perthitic as well a granular exsolution modified the primary feldspar upon cooling. Accessory minerals include titanite, apatite, ilmenite and magnetite. Late metamorphic overprint led to the formation of secondary minerals such as garnet and biotite. Low-grade alteration led to the formation chlorite, sericite, calcite, actinolite and leucoxene. Biotite and actinolite generally replace pyroxene. This secondary biotite contains less than $2 \%$ $\mathrm{TiO}_{2}$ and coexists with leucoxene indicating that the alteration occurred at ca. $600^{\circ} \mathrm{C}$ ( $\mathrm{Luhr}$ and Schreurs).

\section{Analytical results}

\section{1. $\mathrm{Pb}-\mathrm{Pb}$ zircon evaporation ages}

Individual zircons from three syenites were dated by the $\mathrm{Pb}-\mathrm{Pb}$ evaporation method of Kober and Kober. The syenites contain two populations of zircon crystals. The first group of zircons is stubby, anhedral to subhedral, brown and contains visible cores when observed under the binocular microscope. The second group is euhedral, elongated, brown and has no visible inherited core. The anhedral crystals yield ${ }^{207} \mathrm{~Pb} /{ }^{206} \mathrm{~Pb}$ ages from 2667 to $2837 \mathrm{Ma}$ (Table 2). The euhedral zircons yield ages of $2321 \pm 1$ Ma for a two-pyroxene syenite (sample 9398A) and 2349 $\pm 1 \mathrm{Ma}$ for a clinopyroxene syenite (sample 80C-43) (Table 2). The older ages are similar to evaporation ages obtained on the members of the TTG suite and K-rich granitoids surrounding the syenite intrusions (Tchameni, 1997). These older zircon ages may not define a real age, but only a minimum age, if they were partially reset by recrystallization (Mezger and Krogstad, 1997). A proper interpretation of these old ages is only possible after more age constraints become available from the Ntem complex. Nevertheless, these older ages indicate the presence of inherited zircons that are related to some Archean thermal event in the source of the syenites. These old zircon or may indicate derivation of the syenites from crustal material with an age similar to the country rock material or contamination of the syenite melt with material derived from the surrounding gneisses.

The ages from the euhedral zircons are interpreted to date the time of syenite intrusion. This young age is consistent with the field relationships that require the syenite to be younger than the late K-rich granitoids which yielded zircons with ${ }^{207} \mathrm{~Pb} /{ }^{206} \mathrm{~Pb}$ evaporation ages of $2.66 \mathrm{Ga}$ (Tchameni and Tchameni) and older than metadolerite dikes that have formed at of $2059 \pm 16$ $\mathrm{Ma}$ as indicated by Sm-Nd whole rocks isochron. (Tchameni, 1997). A K-Ar age of $807 \pm 24$ Ma for a K-feldspar (Kornprobst et al., 1976) obtained from the clinopyroxene syenite dates a metamorphic overprint following the emplacement of the syenite. This late overprint is most likely related to the overthrusting of crustal nappes during the Pan-African orogeny that also affected the northern part of the Ntem Complex. 
Table 2. Zircon $\mathrm{Pb}-\mathrm{Pb}$ evaporation ages

\begin{tabular}{llllll}
\hline Samples & Morphology of the analyzed zircons & $\begin{array}{l}\text { Number } \\
\text { of scans }\end{array}$ & $T\left[{ }^{\circ} \mathrm{C}\right]$ & ${ }^{207} \mathrm{~Pb} /{ }^{206} \mathrm{~Pb}$ & $\begin{array}{l}\mathrm{Age}\left({ }^{207} \mathrm{~Pb} /{ }^{206} \mathrm{~Pb}\right) \\
(2 \sigma)[\mathrm{Ma}]\end{array}$ \\
\hline Two-pyroxene syenite (9398A) & $\begin{array}{l}\text { elongated, euhedral, no zoning, } \\
\text { brown-red }\end{array}$ & 105 & 1582 & $0.14781 \pm 9$ & $2321 \pm 1$ \\
Clinopyroxene syenite (80C-43) & $\begin{array}{l}\text { short, prismatic, brown-red } \\
\text { anhedral to subhedral brown, }\end{array}$ & 75 & 1580 & $0.15028 \pm 8$ & $2349 \pm 1$ \\
& $\begin{array}{l}\text { visible inherited core } \\
\text { anhedral, brown-clear }\end{array}$ & 63 & 1590 & $0.19582 \pm 12$ & $2792 \pm 1$ \\
anhedral, brown & 65 & 1589 & $0.20134 \pm 16$ & $2733 \pm 2$ \\
& $\begin{array}{l}\text { anhedral, brown, } \\
\text { visible inherited core }\end{array}$ & 70 & 1593 & $0.18147 \pm 3$ & $2667 \pm 1$ \\
& & & & & \\
&
\end{tabular}

\subsection{Major and trace elements}

Despite their petrographic differences the two-pyroxene and clinopyroxene syenites from the Ntem Complex are remarkably similar with respect to their major and trace element geochemistry (Table 1, Fig. 3 and Fig. 4). In terms of normative mineralogy, the rocks straddle the boundary between qtz and ne-normative syenites. The normative alkali feldspar component generally makes up more than $60 \%$ and can be as high as $80 \%$; most of the remainder is pyroxene and anorthite. Due to the lack of significant modal amphibole and micas, the normative mineralogy is almost identical to the modal mineralogy. The two syenite suites show a small variation in their $\mathrm{SiO}_{2}$ contents from 54.9 to $61.9 \mathrm{wt} . \%$. The two-pyroxene syenites have slightly higher $\mathrm{Al}_{2} \mathrm{O}_{3}$ and slightly lower $\mathrm{K}_{2} \mathrm{O}$ contents than the clinopyroxene syenites. On average, the two-pyroxene syenites have higher $\mathrm{Na}_{2} \mathrm{O}+\mathrm{K}_{2} \mathrm{O}, \mathrm{Ba}$, and $\mathrm{Rb}$ contents than the clinopyroxene syenites. The clinopyroxene syenites have on average higher total REEs (Fig. 5) and trace element contents. However, the shape of the REE patterns and the spidergrams (Fig. 6) are quite similar for both syenite suites. With the exception of two samples (ND9213 and TR9235) both clinopyroxene syenites and the two-pyroxene syenites can be classified as high- $\mathrm{K}$ rocks with $\mathrm{K}_{2} \mathrm{O}>4 \%, \quad \mathrm{Na}_{2} \mathrm{O}+\mathrm{K}_{2} \mathrm{O}=7.2-12.1 \%$ ), $\mathrm{FeOt} /(\mathrm{FeOt}+\mathrm{MgO})=0.6-0.8$ and $\mathrm{K}_{2} \mathrm{O} / \mathrm{Na}_{2} \mathrm{O}=1.2-3.8$. These major element signatures are typical for A-type granitoids (alkaline, anhydrous or anorogenic).

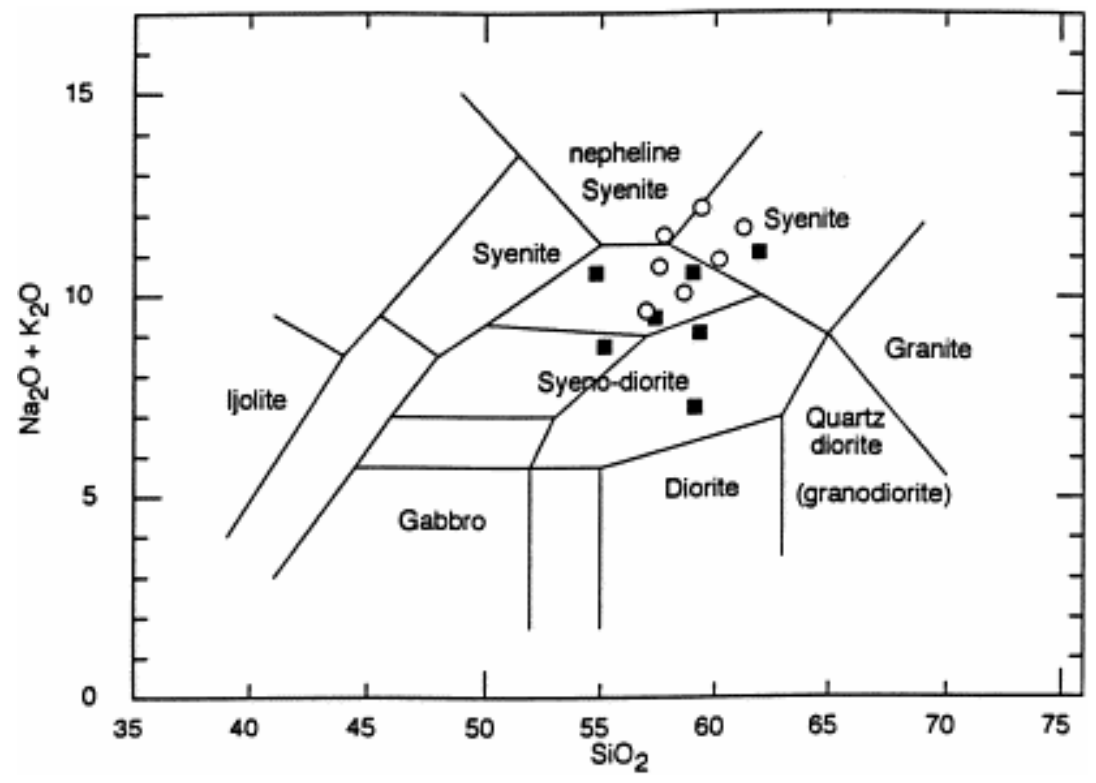

Fig. 3. $\mathrm{SiO}_{2}$ vs. $\mathrm{Na}_{2} \mathrm{O}+\mathrm{K}_{2} \mathrm{O}$ classification diagram of $\mathrm{Cox}$ et al. (1979) with the samples from Ntem Complex. Open circles: clinopyroxene syenites, filled squares: two-pyroxene syenites. 

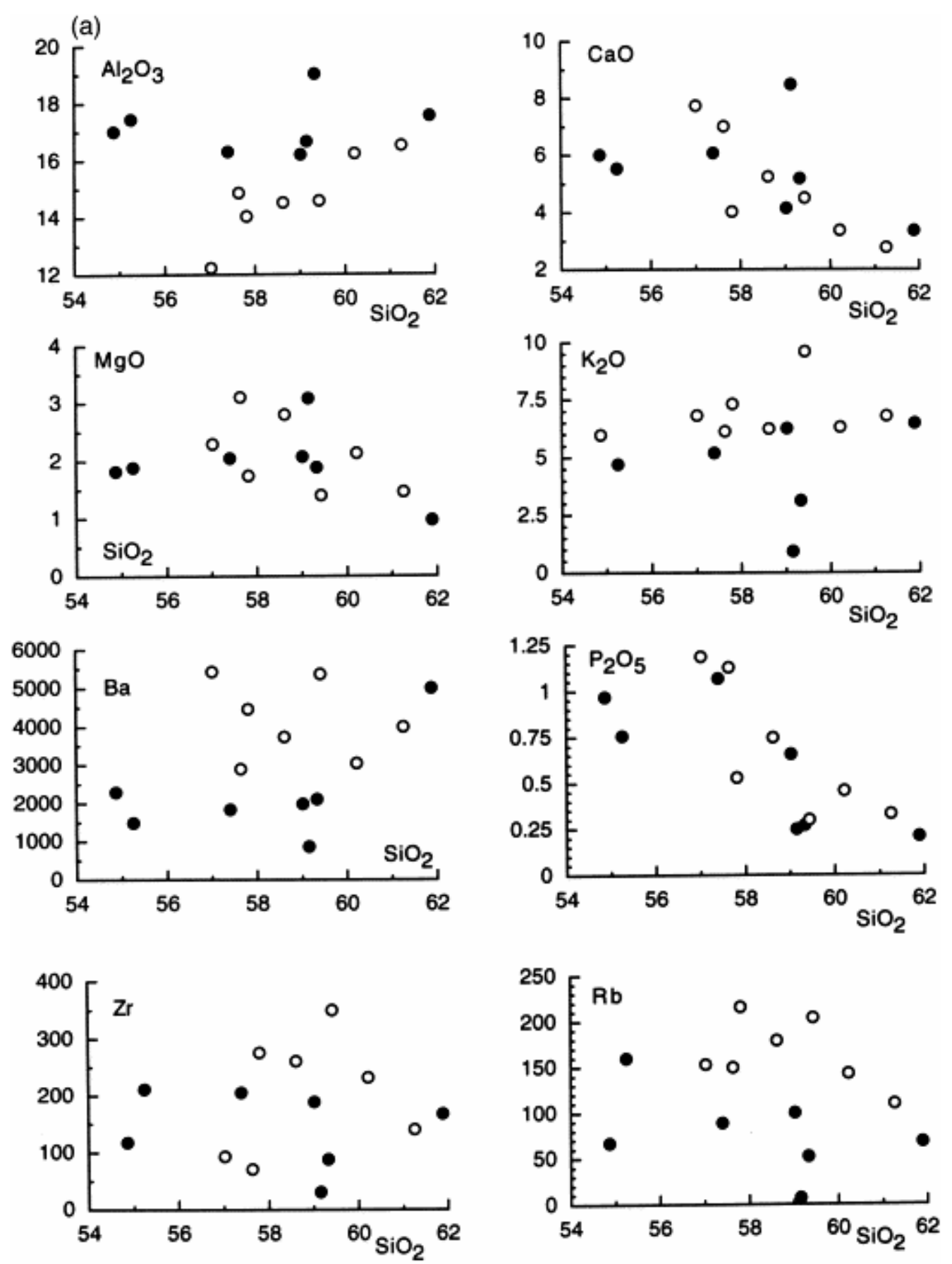

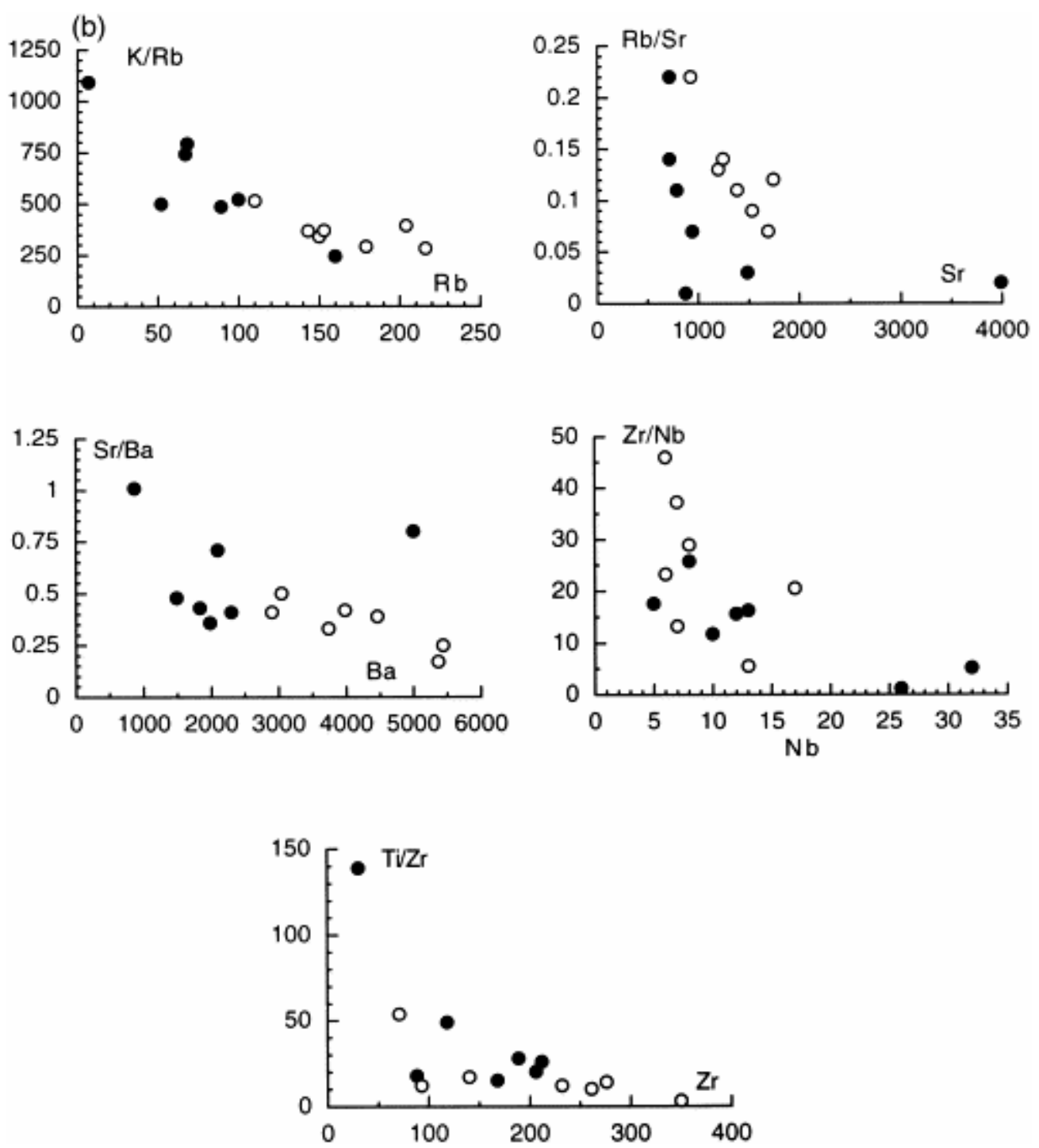

Fig. 4. Harker diagrams for selected major and trace elements and element ratio diagrams for selected trace elements. These diagrams show only vaguely defined trends for the clinopyroxene syenites and not distinct trends for the two-pyroxene syenites thus supporting a complex genesis for the syenites. Open circles: clinopyroxene syenites, filled circles: two-pyroxene syenites.

The clinopyroxene syenites particularly have higher LREE contents with Ce ranging from 205 to $408 \mathrm{ppm}$. All the syenites show highly-fractionated, steep REE patterns and no or only a small Eu anomaly. Most of the elements do not show any systematic variations on Harker diagrams (Fig. 4). Despite their narrow range in $\mathrm{SiO}_{2}$ contents, the alkali and alkali earth elements display variations by a factor of $2-3$. The variation of the REEs is almost one order of magnitude (Fig. 5, Table 3). Transition-element contents are typically low with Ni ranging from 5 to $48 \mathrm{ppm}$ and $\mathrm{Cr}$ from the detection limit to $97 \mathrm{ppm}$. The limited variation in $\mathrm{Y}$ (23 to $51 \mathrm{ppm}$ ) contrasts with large variations in $\mathrm{TiO}_{2}(0.18 \mathrm{wt} . \%$ to $0.97 \mathrm{wt} . \%)$ and $\mathrm{Zr}$ (31 to 350 ppm). 

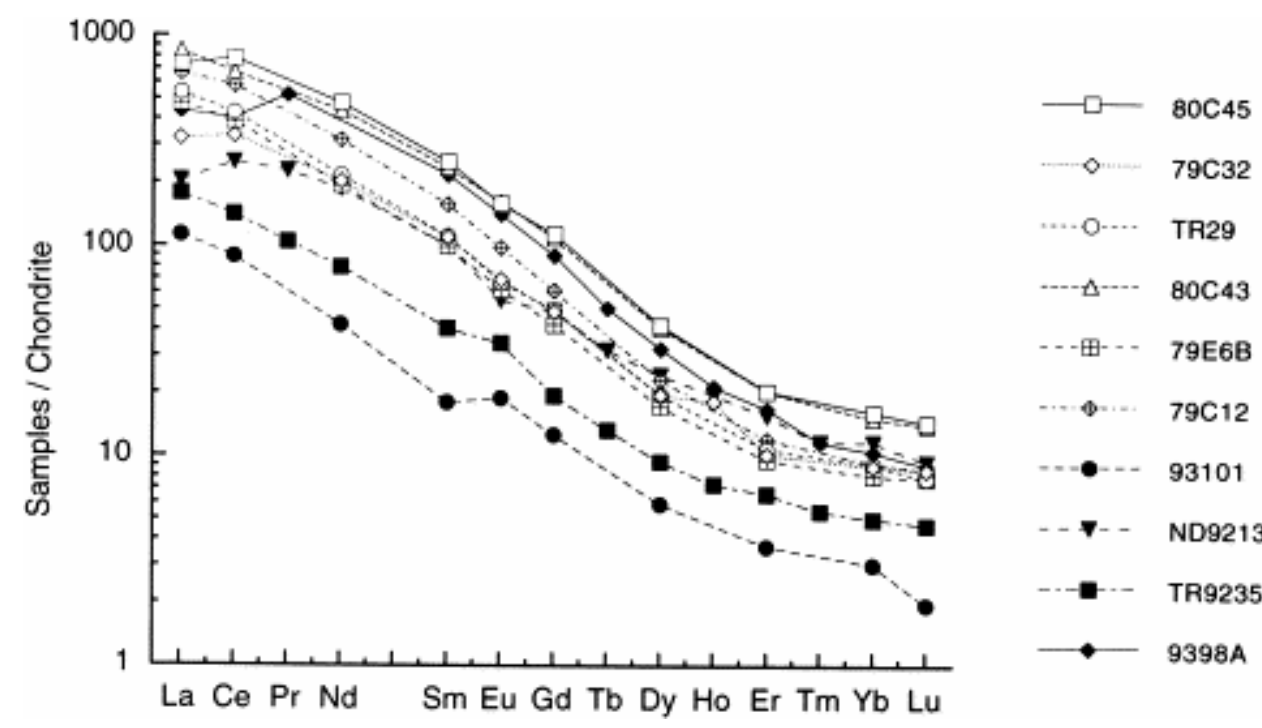

Fig. 5. REE diagram for selected syenites from the Ntem Complex.

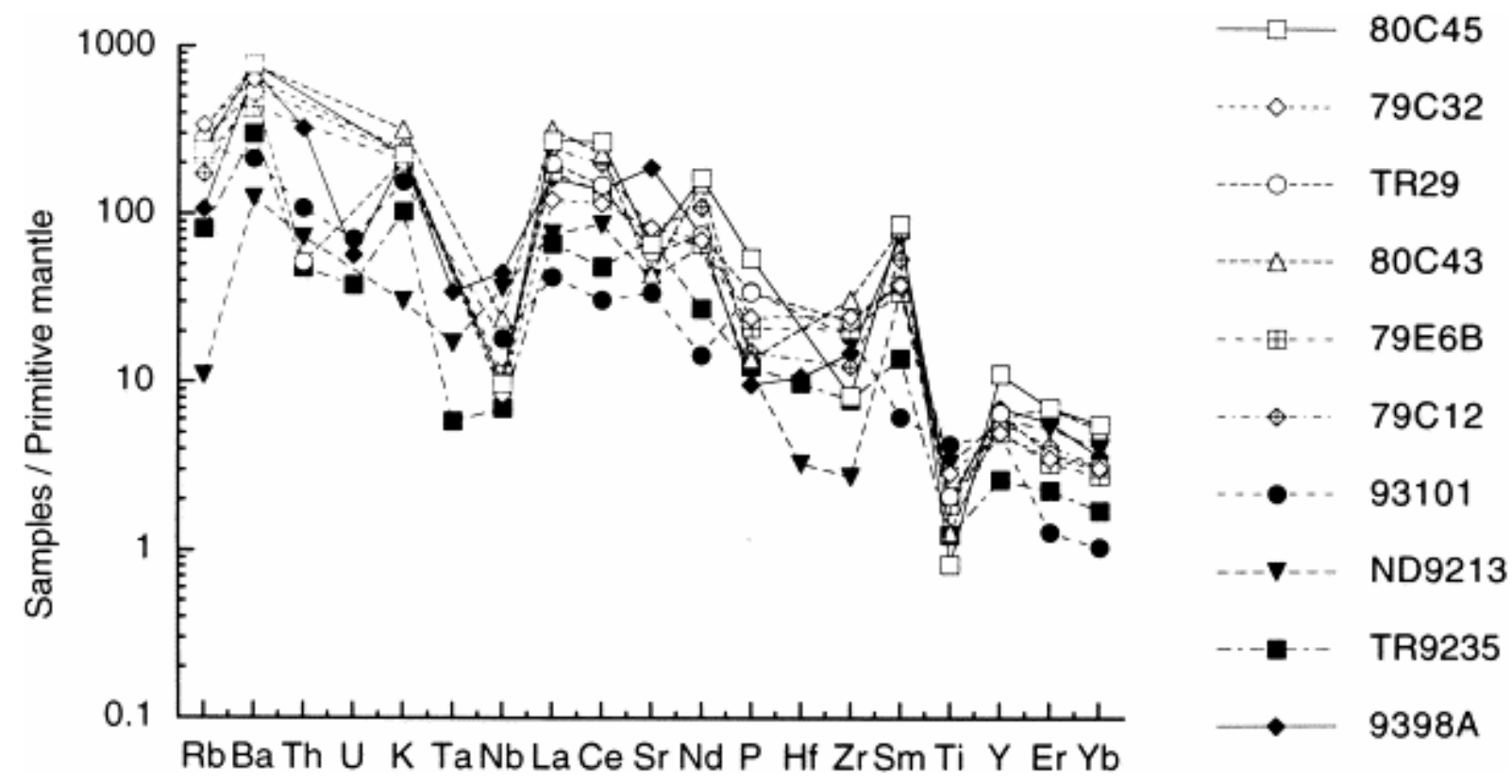

Fig. 6. Trace element diagram for selected syenites from the Ntem Complex. The pronounced negative $\mathrm{Nb}-\mathrm{Ta}$ and $\mathrm{Ti}$ anomalies can be taken as evidence for the crustal origin of the syenites (normalizing values from Sun and McDonough, 1989). 
Table 3. Rare earth element (REE) compositions ( $r=$ replicate analysis)

\begin{tabular}{|c|c|c|c|c|c|c|c|c|c|c|c|}
\hline \multirow[t]{2}{*}{ Samples } & \multicolumn{7}{|c|}{ Clinopyroxene syenites } & \multicolumn{4}{|c|}{ Two-pyroxene syenites } \\
\hline & $80 C 45$ & $79 \mathrm{C} 32$ & TR29 & $80 \mathrm{C} 43$ & 79E6B & 79E6B-r & $79 \mathrm{C} 12$ & 93101 & ND9213 & TR9235 & $9398 \mathrm{~A}$ \\
\hline$\overline{\mathrm{La}}$ & 188 & 83.5 & 138 & 219 & 119 & 122 & 170 & 29.1 & 52.5 & 45.8 & 112 \\
\hline $\mathrm{Ce}$ & 478 & 205 & 264 & 408 & 227 & 239 & 354 & 54.6 & 153 & 86.5 & 248 \\
\hline $\operatorname{Pr}$ & - & - & - & - & - & 26.0 & - & - & 21.6 & 10.0 & - \\
\hline $\mathrm{Nd}$ & 223 & 94.7 & 101 & 206 & 90.3 & 90.4 & 149 & 19.7 & 87.2 & 37.1 & 101 \\
\hline $\mathrm{Sm}$ & 38.5 & 16.9 & 17.0 & 36.1 & 13.8 & 15.2 & 24.1 & 2.77 & 15.4 & 6.2 & 33.3 \\
\hline $\mathrm{Eu}$ & 9.2 & 4.0 & 3.9 & 9.4 & 3.7 & 3.6 & 5.7 & 1.1 & 3.2 & 2.0 & 8.2 \\
\hline $\mathrm{Gd}$ & 23.5 & 10.0 & 10.2 & 22.4 & 8.96 & 8.70 & 12.6 & 2.60 & 10.1 & 4.0 & 18.5 \\
\hline $\mathrm{Tb}$ & - & - & - & - & 1.08 & - & - & - & 1.2 & 0.5 & 1.9 \\
\hline Dy & 10.7 & 5.0 & 5.0 & 10.4 & 4.8 & 4.4 & 5.9 & 1.5 & 6.2 & 2.4 & 8.3 \\
\hline $\mathrm{Ho}$ & - & 1.0 & - & - & 0.63 & - & - & - & 1.1 & 0.4 & 1.2 \\
\hline $\mathrm{Er}$ & 3.4 & 1.7 & 1.8 & 3.4 & 1.9 & 1.6 & 2.0 & 0.62 & 2.6 & 1.1 & 2.8 \\
\hline $\operatorname{Tm}$ & - & - & - & - & 0.2 & - & - & - & 0.3 & 0.14 & 0.3 \\
\hline $\mathrm{Yb}$ & 2.8 & 1.5 & 1.6 & 2.6 & 1.4 & 1.4 & 1.6 & 0.52 & 2.0 & 0.86 & 1.8 \\
\hline $\mathrm{Lu}$ & 0.37 & 0.22 & 0.20 & 0.36 & 0.22 & 0.2 & 0.22 & 0.05 & 0.24 & 0.12 & 0.23 \\
\hline$(\mathrm{La} / \mathrm{Yb}) \mathrm{N}$ & 44.6 & 36.1 & 58.0 & 55.7 & 58.4 & 59.9 & 70.8 & 37.0 & 17.4 & 35.2 & 42.3 \\
\hline $\mathrm{Eu} / \mathrm{Eu}^{*}$ & 0.87 & 0.87 & 0.84 & 0.94 & 0.88 & 0.88 & 0.90 & 1.23 & 0.74 & 1.15 & 0.92 \\
\hline $\mathrm{YbN}$ & 16.41 & 9.00 & 9.24 & 15.29 & 8.12 & 8.12 & 9.35 & 3.06 & 11.76 & 5.06 & 10.59 \\
\hline
\end{tabular}

Diagnostic chemical features that allow the syenites from the Ntem complex to be classified as A-type granitoids include: high alkali contents, high $\mathrm{FeO} / \mathrm{MgO}$, high LREE contents, elevated $\mathrm{Ga} / \mathrm{Al}$ ratios and low $\mathrm{CaO}$ contents and low abundances of transitional elements (Collins and Whalen). The majority of known A-type granitoids have been emplaced into non-compressive environments (Collins and Eby) although this is not a necessary prerequisite for all of these granitoids (Whalen et al., 1987). Several petrogenetic models have been proposed to explain the geochemical characteristics of A-type granitoids in general. The key processes involved in these models are: (1) extended fractionation of basaltic magma to produce residual granitic liquids (Turner et al., 1992); (2) partial melting of tonaliticgranodioritic rocks (Anderson and Creaser); (3) metasomatic alterations of pre-existing granite through interaction with F, Cl and alkali-rich solutions (Taylor, 1980); (4) remelting of lower crustal rocks from which a previous melt had been extracted (Collins and Clemens). Most probably, several mechanisms rather than a single common process are responsible for the petrogenesis of A-type granitoids (Eby, 1992).

Any model for the genesis of the syenites in the Ntem Complex has to account for a few key chemical characteristics that distinguish these syenites from all the other rocks in the complex. Particularly striking in these feldspar dominated rocks is the extreme enrichment of the REEs and the lack of a pronounced $\mathrm{Eu}$ anomaly, with $\mathrm{Eu} / \mathrm{Eu}^{*}$ from 0.9 to 1.23. Other extremely enriched elements include $\mathrm{Sr}, \mathrm{Ba}$ and $\mathrm{K}$. The large variability in the concentrations of the trace elements compared to the small variation in $\mathrm{SiO}_{2}$ contents precludes a simple petrogenesis for the syenites. It is much more likely that several processes and/or sources were involved in the formation of these alkaline rocks.

\subsection{Isotope systematics}

The $\mathrm{Nd}$ and $\mathrm{Sr}$ isotope compositions of selected whole rock samples are given in Table 4 and Table 5. The $\mathrm{Pb}$-isotope ratios were determined on four acid leached $\mathrm{K}$-feldspar separates (Table 6). As shown in Fig. 7, the isotope systematics of $\mathrm{Nd}$ provide a much simpler picture of the syenites than the major and trace elements. In a regular isochron diagram, the two groups of syenites the samples are correlated along a line that corresponds to an age of $\left.2347 \pm 210 \mathrm{Ma},\left(\varepsilon \mathrm{Nd}=-6.6,{ }^{143} \mathrm{Nd} /{ }^{144} \mathrm{Nd}\right)_{0}=0.50926 \pm 14, \mathrm{MSWD}=7\right)$. The sizable uncertainty of the $\mathrm{Sm}-\mathrm{Nd}$ isochron is a consequence of the small range of ${ }^{147} \mathrm{Sm} /{ }^{144} \mathrm{Nd}(0.0929-0.1207)$. The 
narrow range in the initial $\varepsilon \mathrm{Nd}_{(2320)}$ from -5.8 to -7.5 for the two groups of syenites is quite unexpected because the samples were collected from two distinct plutons and over a large area. As indicated by the variations of the trace elements, the syenites are unlikely to have the same parental material. The age given by the isochron can be meaningful, if the different sources of the syenites had similar isotope composition and the major fractionation of $\mathrm{Sm}-\mathrm{Nd}$ happened during the formation of the syenites. A linear array in an isochron plot can also be achieved through two-component mixing. This explanation is unlikely in view of the zircon ages presented above and the $\mathrm{Sr}$ isotope systematics discussed below. The $\mathrm{Sm}-\mathrm{Nd}$ isochron age is similar to the youngest $\mathrm{Pb}-\mathrm{Pb}$ zircon evaporation ages. The correlation of the samples in the isochron plot and the similarity of the $\mathrm{Sm}-\mathrm{Nd}$ age with the $\mathrm{Pb}-\mathrm{Pb}$ zircon ages of 2321 and $2349 \mathrm{Ma}$ from the same samples suggests a genetic and temporal link between the two groups of the syenites. It indicates that the two types of syenite formed at about the same time and that their sources had similar Nd-isotope compositions.

Table 4. Nd isotopes and $\mathrm{Nd}$ and $\mathrm{Sm}$ abundances

\begin{tabular}{|c|c|c|c|c|c|c|c|c|}
\hline Samples & $\mathrm{Sm}(\mathrm{ppm})$ & $\mathrm{Nd}(\mathrm{ppm})$ & ${ }^{143} \mathrm{Nd} /{ }^{144} \mathrm{Nd}$ & $2 \sigma$ & ${ }^{147} \mathrm{Sm} /{ }^{144} \mathrm{Nd}$ & $\left({ }^{143} \mathrm{Nd} /{ }^{144} \mathrm{Nd}\right) T$ & $\varepsilon \mathrm{Nd}_{2.32}$ & $T_{\mathrm{DM}}$ \\
\hline \multicolumn{9}{|c|}{ Two-pyroxene syenites } \\
\hline ND9213 & 16.48 & 91.89 & 0.510920 & 9 & 0.1084 & 0.509263 & -7.5 & 3222 \\
\hline 9398B & 5.180 & 29.37 & 0.510894 & 13 & 0.1067 & 0.509263 & -7.4 & 3208 \\
\hline TR9235 & 14.37 & 78.16 & 0.511013 & 15 & 0.1112 & 0.509313 & -5.8 & 3174 \\
\hline $9223 \mathrm{~S}$ & 18.19 & 116.1 & 0.510729 & 14 & 0.0947 & 0.509281 & -7.1 & 3095 \\
\hline \multicolumn{9}{|c|}{ Clinopyroxene syenites } \\
\hline $79 \mathrm{E}-6 \mathrm{~B}$ & 12.43 & 80.85 & 0.510684 & 12 & 0.0929 & 0.509264 & -7.5 & 3106 \\
\hline 81LOL-4 & 113.1 & 566.6 & 0.511102 & 11 & 0.1207 & 0.509257 & -7.5 & 3351 \\
\hline $80 \mathrm{C}-45$ & 36.01 & 220.9 & 0.510799 & 13 & 0.0985 & 0.509293 & -7.3 & 3105 \\
\hline $80 \mathrm{C}-43$ & 36.10 & 206.0 & 0.511237 & 12 & 0.1271 & 0.509294 & -6.5 & 3363 \\
\hline $79 \mathrm{C}-32$ & 50.77 & 241.5 & 0.510777 & 11 & 0.0981 & 0.509277 & -6.2 & 3123 \\
\hline
\end{tabular}

Table 5. Sr isotopes and $\mathrm{Sr}$ and $\mathrm{Rb}$ abundances

\begin{tabular}{|c|c|c|c|c|c|c|c|}
\hline Samples & $\mathrm{Rb}(\mathrm{ppm})$ & $\mathrm{Sr}(\mathrm{ppm})$ & ${ }^{87} \mathrm{Sr} /{ }^{86} \mathrm{Sr}$ & $2 \sigma$ & ${ }^{87} \mathrm{Rb} /{ }^{86} \mathrm{Sr}$ & $\left({ }^{87} \mathrm{Sr} /{ }^{86} \mathrm{Sr}\right) \mathrm{T}$ & $\varepsilon \mathrm{Sr}_{2.32}$ \\
\hline \multicolumn{8}{|c|}{ Two-pyroxene syenites } \\
\hline ND9213 & 7 & 875 & 0.702305 & 6 & 0.0231 & 0.701531 & -2.8 \\
\hline 9398B & 21 & 1528 & 0.702252 & 11 & 0.0397 & 0.700922 & -11.5 \\
\hline TR9235 & 52 & 1486 & 0.702257 & 12 & 0.1012 & $(0.698868)$ & $(-40.8)$ \\
\hline $9323 \mathrm{~S}$ & 100 & 716 & 0.716632 & 10 & 0.4044 & 0.703088 & 19.3 \\
\hline \multicolumn{8}{|c|}{ Clinopyroxene syenites } \\
\hline $79 \mathrm{E}-6 \mathrm{~B}$ & 143 & 1531 & 0.711408 & 11 & 0.2703 & 0.702355 & 8.9 \\
\hline 81LOL-4 & 226 & 2285 & 0.713258 & 10 & 0.2863 & 0.703669 & 27.6 \\
\hline $80 \mathrm{C}-45$ & 153 & 1383 & 0.713260 & 11 & 0.3202 & 0.702536 & 11.9 \\
\hline $80 \mathrm{C}-43$ & 204 & 925 & 0.711404 & 10 & 0.6392 & $(0.689995)$ & $(-167)$ \\
\hline $79 \mathrm{C}-32$ & 216 & 1744 & 0.725362 & 11 & 0.3585 & 0.713355 & 166 \\
\hline
\end{tabular}

Table 6. Pb isotopes of acid-leached K-feldspars

\begin{tabular}{llllll}
\hline Samples & ${ }^{206} \mathrm{~Pb} /{ }^{204} \mathrm{~Pb}$ & ${ }^{207} \mathrm{~Pb} /{ }^{204} \mathrm{~Pb}$ & ${ }^{208} \mathrm{~Pb} /{ }^{204} \mathrm{~Pb}$ & $\mu_{1}$ & Model age \\
\hline TR9235 & 14.429 & 15.089 & 34.612 & 11.0 & 2515 \\
79E6B & 13.935 & 14.911 & 35.045 & 11.2 & 2727 \\
$80 \mathrm{C}-43$ & 14.390 & 14.999 & 35.317 & 10.0 & 2401 \\
$79 \mathrm{C}-32$ & 14.100 & 14.947 & 35.150 & 10.7 & 2610 \\
\hline
\end{tabular}




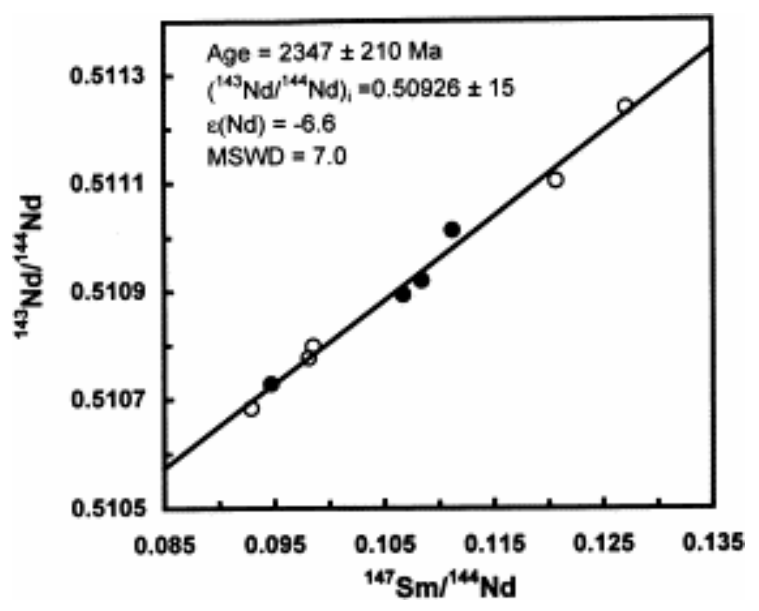

Fig. 7. Sm-Nd isochron diagram for the syenites from the Ntem Complex. The age defined by the slope of the isochron corresponds to the Pb-evaporation age obtained from magmatic zircons. Symbols as in Fig. 4.

In the syenites, the $\mathrm{Rb}-\mathrm{Sr}$ system displays a more complex behavior than the $\mathrm{Sm}-\mathrm{Nd}$ system (Fig. 8). Assuming an age of $2630 \mathrm{Ma}$ for the time of intrusion of both syenite suites, the initial ${ }^{87} \mathrm{Sr} /{ }^{86} \mathrm{Sr}$ ratios show a large variation, some of them are even unrealistically low, with ${ }^{87} \mathrm{Sr} /{ }^{86} \mathrm{Sr}$ values below 0.7 (Table 5). The initial ${ }^{87} \mathrm{Sr} /{ }^{86} \mathrm{Sr}$ value require that the $\mathrm{Rb} / \mathrm{Sr}$ ratio in these samples was modified after emplacement. The timing of this change in the $\mathrm{Rb} / \mathrm{Sr}$ cannot be constrained but may be related to the Pan-African orogeny that affected the syenites as indicated by the K-Ar age of $807 \pm 24$ Ma obtained by Kornprobst et al. (1976) for a Kfeldspar from the clinopyroxene syenite. It is possible that the other samples are also affected by this event, but since they yield realistic initial ${ }^{87} \mathrm{Sr} /{ }^{86} \mathrm{Sr}$ values there is no reason to assume that their $\mathrm{Rb} / \mathrm{Sr}$ system was disturbed. The samples that plot close to the reference isochron in Fig. 9 still display significant scatter that points to a heterogeneous source of the syenite melts. This observation is consistent with the observed Nd-isotope systematics.

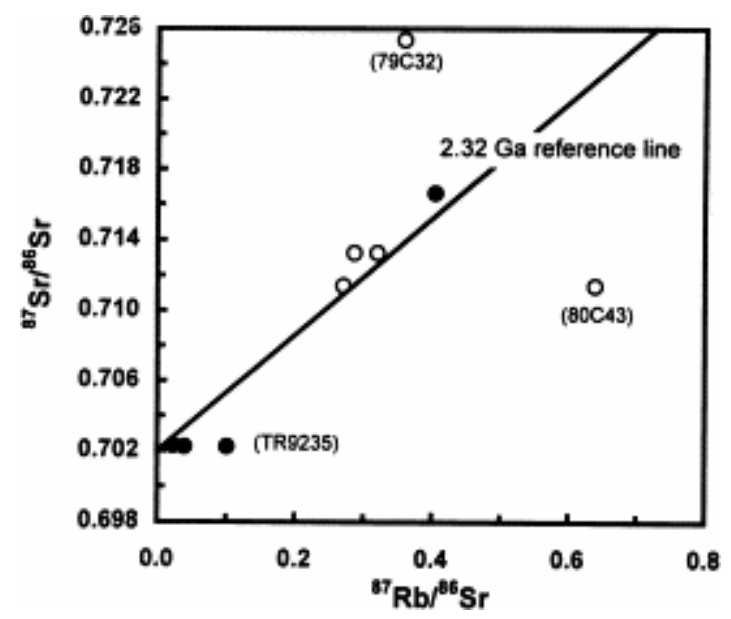

Fig. 8. Rb-Sr diagram for the syenites from the Ntem Complex. The reference line corresponds to the age obtained for magmatic zircons. Samples in parentheses may have been affected by post-emplacement alteration. Symbols as in Fig. 4. 

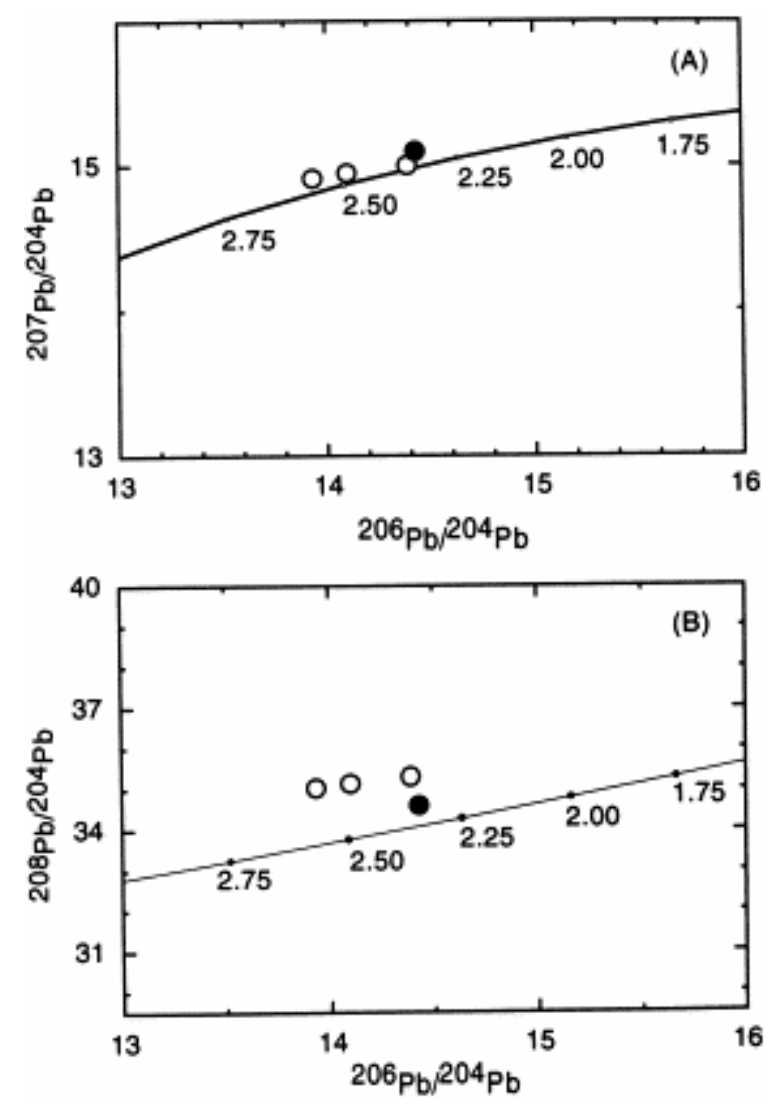

Fig. 9. Pb-isotope diagrams for leached K-feldspars. The line is the orogenic reference line taken from Doe and Zartmann (1979). Assuming closure of the system for equilibration with the whole rock, the Pb isotopes indicate an early U depletion and slight Th/U enrichment. Symbols as in Fig. 4.

The $\mathrm{Pb}$ isotopes from leached K-feldspars (Table 6) plot in a narrow array in the ${ }^{206} \mathrm{~Pb} /{ }^{204} \mathrm{~Pb}-$ ${ }^{207} \mathrm{~Pb} /{ }^{204} \mathrm{~Pb}$ and ${ }^{206} \mathrm{~Pb} /{ }^{204} \mathrm{~Pb}-{ }^{208} \mathrm{~Pb} /{ }^{204} \mathrm{~Pb}$ diagrams (Fig. 9). The $\mathrm{Pb}$ isotopes are slightly retarded considering the $\mathrm{K}$-feldspars closed for $\mathrm{Pb}$ diffusion during the last regional metamorphism defined by a K-Ar age of $807 \pm 24$ Ma for a K-feldspar (Kornprobst et al., 1976). The $\mathrm{Pb}$ model ages point to an Archean source with a $\mu_{1}$ of 10-11 (Table 6). With respect to the Doe and Zartmann (1979) $\mathrm{Pb}$ evolution model, the $\mathrm{Pb}$ in the syenites has ${ }^{207} \mathrm{~Pb} /{ }^{204} \mathrm{~Pb}$ ratios that indicate an early history with a slightly elevated $\mu$ value followed by a depletion in $\mathrm{U}$. The ${ }^{208} \mathrm{~Pb} /{ }^{204} \mathrm{~Pb}$ indicate a slightly elevated $\mathrm{Th} / \mathrm{U}$, a feature that is widespread in rocks of lower crustal origin. Thus, the $\mathrm{Pb}$ isotopes suggest that the source for the syenites had a multistage prehistory. Thus, all three isotope system, $\mathrm{Nd}, \mathrm{Sr}$ and $\mathrm{Pb}$, indicate that the syenites were derived from material with an extended differentiation history prior to the emplacement of the intrusions.

\section{Discussion}

The poor correlation of the different major and trace elements as well as the complex isotope systematics preclude a simple origin for the syenites. The initial ${ }^{143} \mathrm{Nd} /{ }^{144} \mathrm{Nd}$ ratios are more robust than the initial $\mathrm{Sr}$ isotopic ratios because, in general, the REEs fractionate considerably less during crustal process than the $\mathrm{Rb} / \mathrm{Sr}$ ratios. Therefore, particularly the $\mathrm{Nd}$ isotopes provide some firm constraints on the source rocks of the syenites. The Nd model ages are high with $T_{\mathrm{DM}}$ values ranging from 3.1 to $3.4 \mathrm{Ga}$. The initial $\varepsilon N d$ values for the syenite samples at the presumed time of intrusion range from -5.8 to -7.5 (Table 4 ). These values are exactly 
within the range defined by the evolution of the greenstone belt rocks and the members of the TTG suite that make up the major part of the Ntem Complex (Tchameni, 1997). This relationship is shown in an $\varepsilon N d$ vs. time diagram in Fig. 10. The $\mathrm{Nd}$ isotopes thus indicate that the syenites can be completely derived from material with $\mathrm{Sm}-\mathrm{Nd}$ characteristics identical to those of the surrounding gneisses. If any primitive or depleted mantle material was directly involved in the genesis of the syenites, this evidence is not visible in the Ndisotope systematics as shown in Fig. 10. The concentrations of $\mathrm{Nd}$ are quite high in all the syenites (Table 4) and thus, a contribution of mantle material, that has typically much lower concentrations of $\mathrm{Nd}$, may not be detectable. In turn this high concentration of $\mathrm{Nd}$ and the isotope signature also indicate that the dominant part of the syenitic material was derived from a long-term LREE enriched source and the depleted mantle is a most unlikely contributor in the petrogenesis.

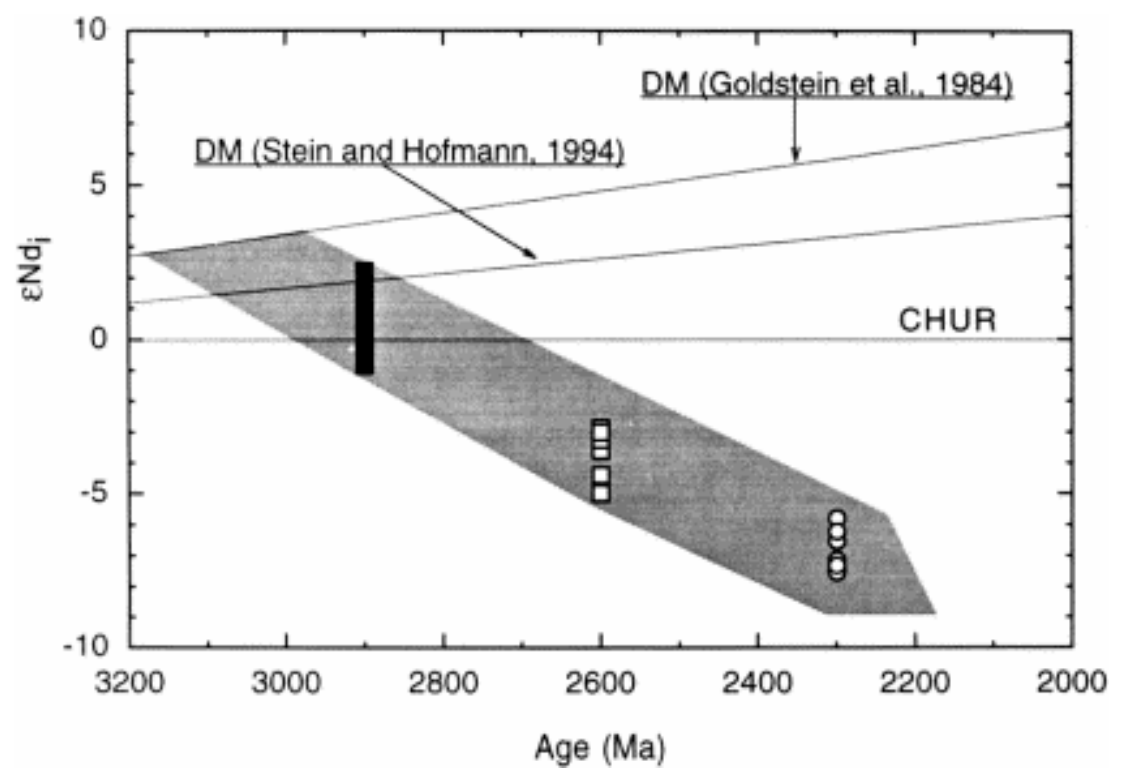

Fig. 10. Nd-evolution diagram. The syenites are shown as open circles. The open squares indicate the Nd isotope composition of late granites. The Nd isotope composition of all the Archean gneisses (members of the TTG suite, biotite gneisses and greenstone belt lithologies) surrounding the syenites are shown as filled squares. Gray area shows trajectory for the $\mathrm{Nd}$ evolution of the Archean gneisses (isotope data from Tchameni, 1997). DM: Goldstein and Stein.

The complexities in the $\mathrm{Rb}-\mathrm{Sr}$ isotope system also point towards a source that had a heterogeneous $\mathrm{Rb} / \mathrm{Sr}$ distribution and a long pre-history thus excluding a homogeneous mantle source. The Sr isotopes are broadly consistent with a derivation of the syenites from material similar to the surrounding gneisses. The combined $\mathrm{Nd}$ and $\mathrm{Sr}$ isotope ratios indicate that all syenites from the Doum-Lolodorf and Mengueme areas can be derived from material with an isotope signature identical to that of the vast majority of the older rocks represented by greenstone belts, TTG suite and late high-K granitoids of the whole Ntem Complex (Tchameni, 1997). In addition, the ubiquitous presence of inherited zircons in the syenites, with minimum $\mathrm{Pb}-\mathrm{Pb}$ ages between 2.67 and $2.84 \mathrm{Ga}$, provides unambiguous mineralogical evidence for the involvement of older crustal material.

If the syenites are derived from rocks that are not only isotopically similar to the exposed rocks of the Ntem complex, but if equivalents of these rocks were also the actual source for the syenites, then major enrichments in the REEs as well as alkalis and alkali earth elements were necessary to produce these enriched syenitic melts. The prominent chemical feature of 
the syenites is the overall very strong enrichment in incompatible elements as shown by the REE patterns in Fig. 5 and the trace element distributions in Fig. 6. The enrichment is not the same for all elements but is particularly obvious in the case of the LREEs. This enrichment can have happened in principle either in the source, during melting or during fractional crystallization of the syenitic melts.

As shown in Fig. 7 and Table 4, the ${ }^{147} \mathrm{Sm} /{ }^{144} \mathrm{Nd}$ ratios for the syenites range from 0.09 to 0.12 . These ratios are somewhat higher than the average ${ }^{147} \mathrm{Sm} /{ }^{144} \mathrm{Nd}$ ratio of the members of the surrounding Archean gneisses that have an average ${ }^{147} \mathrm{Sm} /{ }^{144} \mathrm{Nd}$ ratio of 0.09 (Tchameni, 1997). If these Archean gneisses are a potential source, this requires a phase in the residuum that prefers the LREEs slightly over the heavy REEs. This increase in $\mathrm{Sm} / \mathrm{Nd}$ compared to the potential source rocks explains the older $\mathrm{Nd}$ model ages for the syenites that range from 3.1 to $3.4 \mathrm{Ga}$ whereas the surrounding rocks of the greenstone belt lithologies and the TTG suite have model ages from ca. 3.0 to $3.1 \mathrm{Ga}$ (Tchameni, 1997).

The high abundances of all the REEs require a mineral assemblage in the residuum or during fractional crystallization that has a bulk partition coefficients for the REE that are $<1$ (Fig. 5 and Fig. 6). The fractional crystallization of feldspar or abundant feldspar in the residuum of the syenites is excluded due to the absence of a pronounced negative Eu anomaly and the high total $\mathrm{Rb}$ and $\mathrm{Sr}$ contents. Similarly, the high $\mathrm{K}, \mathrm{Ba}$ and $\mathrm{Rb}$ cannot be the result of the accumulation of K-feldspar in these rocks because they lack a pronounced positive $\mathrm{Eu}$ anomaly. Fractional crystallization of clinopyroxene can be excluded since this leads only to a minor enrichment or even depletion in the HREEs. This conclusion is also supported by the observation that the syenites show a lower LREE/HREE compared to the potential source rocks and the surrounding gneisses. Other phases that have a pronounced effect on the REE contents are apatite and titanite, both occur as accessory phases in the syenites. However, removal of trace amounts of apatite and titanite result in a severe depletion of the total REE contents, the opposite of what is actually observed. It is possible that these trace phases play some role during the crystallization of the syenites, but their role is insignificant during the genesis of the primary melts. Thus, there is no likely mineral assemblage that can explain the observed trace element characteristics of the syenites by fractional crystallization. It is thus more likely that the enrichment occurred in the source prior to or during melting. Whatever the enriching agent was, a fluid or a melt, it must have come from material with isotopic characteristics just like the exposed greenstone belt lithologies and the TTG suite of the Ntem Complex. If such rocks were a source, potential major residual phases could have been garnet, pyroxene and feldspar. The residual mineral assemblage must have had low partition coefficients for the REEs and thus garnet can have been present only as a trace phase, if it was present at all. This leaves for the residual assemblage only pyroxenes and minor amounts of feldspar such that no Eu anomaly developed and the melt could be enriched in K. The vaporabsent breakdown of biotite in the lower crust to form a silicic melt and residual pyroxene can account for the formation of syenitic melts from members of the TTG suite (Anderson and Creaser) in the lower crust of the Ntem Complex.

The crustal origin of the syenite melt is also indicated by the apparently unsystematic behavior of almost all elements as shown on the Harker diagrams. These variations require a multitude of sources with variable chemical compositions. The syenites have $\mathrm{Mg} \#$ of $0.32-$ 0.65. These values are lower than those observed for the members of the TTG suite or the greenstone belt rocks and similar to those found in the late K-rich granitoids which are the result of partial melting near the level of intrusion (Tchameni, 1997). This can also be taken as further evidence for the syenites to be of crustal origin and there is no need to invoke a 
mafic primary source. The lower crust as a source for the syenite is also supported by the common $\mathrm{Pb}$ data that requires material with a history of $\mathrm{U}$ depletion and increase in the $\mathrm{Th} / \mathrm{U}$ ratio (Fig. 9). Thus, all the geochemical indicators support the lower continental crust as the likely source for these alkaline A-type granitoids in the Ntem Complex. The intrusion temperatures of $<1000^{\circ} \mathrm{C}$ based on the saturation of zircon, monazite and apatite (Tchameni, 1997) and the major mineral assemblage are also compatible with the interpretation that the lower crust of the Ntem Complex is the source of the syenites. In order to achieve the strong enrichment in incompatible elements the syenites must be the result of small-degree partial melting of lower crust (Harris; Woolley; Bailey and Smith). Thus, the syenites were most likely formed by partial melting tonalitic-granodioritic rocks (Anderson and Creaser) as represented by the of the surrounding Archean gneisses.

The cause for these elevated temperatures in the lower crust required for melting may be related to some tectonic activity. It is possible that the syenites formed in response to extension or even rifting. The linear array of the syenite bodies supports a tectonic link, but currently there is no geochronologic information available that indicates major tectonic movement at the time of syenite intrusion. As a result of extensions and crustal thinning, hot mantle may have come into contact with the lower crust and led to partial melting. It is also possible that mafic mantle melts intruded into the lower crust and led to heating and melting without mixing with the crustal melts.

\section{Conclusions}

The observation that syenites were most likely generated at $<1000^{\circ} \mathrm{C}$ (Tchameni, 1997), the presence of the inherited zircons with ages from 2.6 to $2.8 \mathrm{Ga}$ and the high crustal residence ages $\left(T_{\mathrm{DM}}\right)$ ranging from 3.1 to $3.4 \mathrm{Ga}$ compared to the zircon crystallization age of $2.32 \mathrm{Ga}$ imply that the syenites were derived from a felsic crustal source. The trace element patterns, the ranges in isotope and trace element ratios of the syenites overlap with those of the surrounding gneisses of the Ntem Comlex. Thus, these similarities support a genetic link between the syenites and surrounding country rocks. Mafic mantle material as a significant contaminant in the petrogenesis of the syenites is excluded because the $\mathrm{Sr}$ and $\mathrm{Nd}$ isotope characteristics are inconsistent with a primitive or depleted mantle source. The strongly enriched REEs in the syenites would require fractional crystallization of a phase with small $K_{\mathrm{d}} \mathrm{S}$ for the REEs, however, the lack of significant Eu anomalies in the syenites is evidence that the magmas cannot have formed from basaltic liquids by extended fractional crystallization of plagioclase or anorthoclase at crustal levels. Thus, the combined isotope and trace element data as well as the possible intrusion temperatures point to the lower crust as the major source of the post-orogenic syenite intrusions in the Ntem Complex. The degree of melting had to be small to allow for the significant increase in incompatible elements observed in both syenite suites (Harris and Woolley). Limited availability of $\mathrm{H}_{2} \mathrm{O}$ and relatively low oxygen fugacity during partial melting, and high temperatures in the crust, may be all that is required to produce both types of the Early Proterozoic syenites in southern Cameroon by dehydration melting.

These syenites from the Ntem Complex, with their wholly crustal origin, may represent one end member for the different petrogenetic possibilities to generate such alkali-rich rocks that form major intrusive bodies. Most known syenite intrusions that have at least some mantle contribution (e.g., Zanvilevich; Whalen and Harris). Mantle-derived material intruded into the crust and assimilated lower crustal material (e.g., Fitton; Nielsen and Downes) or the syenite 
is though to have been generated in an enriched upper mantle (e.g., Harris; Woolley; Bailey and Smith).

The geotectonic significance of the syenites is still subject to speculation. It is common for alkali intrusions occur in a liner arrangement. This is then generally attributed to a rift setting, because in many well known rift system (e.g., East African Rift, Oslo Graben) alkali intrusions are common and even characteristic for this type of geotectonic setting (e.g., Fitton and Zanvilevich). In the Ntem Complex the syenite suite from the Doum-Lolodorf area shows a linear array of individual intrusive bodies (Fig. 2) and this may be interpreted as an indication for an extensional setting for the these alkali-rich bodies. In this case melting may have been initiated by mantle upwelling or mafic magma influx into a localized area as a result of extension tectonics. The thermal anomaly must have been generated due to large scale tectonic activity in the crust or the mantle. However, so far this, episode of deep-seated thermal activity was not known from this part of the Congo Craton. The Sao Francisco Craton of Brazil, which is generally correlated with the Congo Craton, shows evidence for Palaeoproterozoic reworking. $\mathrm{Rb}-\mathrm{Sr}$ ages of 2250-2130 Ma for granitoids and $\mathrm{U}-\mathrm{Pb}$ ages for titanite and monazite extracted from granitoids, felsic veins and amphibolite enclaves ranging from 2320 to $2030 \mathrm{Ma}$ (Teixeira et al., 1996) indicate magmatic activity in the Sao Francisco Craton that is contemporaneous with the emplacement of the syenites in the Ntem Complex. This possible correlation indicates that the genesis of the syenites may be part of a large scale crustal reworking and tectonothermal event that occurred in a more or less stabilized Archean craton. The formation of the large syenite bodies in the Ntem Complex did not lead to significant additions of crustal material but is evidence for crustal reworking significantly postdating the formation of the surrounding Archean crust. Thus, the syenites of the Ntem Complex are valuable probes for the composition and evolution of the lower crust in the Archean Congo Craton.

\section{Acknowledgements}

We would to thank G. Feyerherd and I. Bambach for their patient help with the diagrams. RT would like to thank the German Academic Exchange Service (DAAD) for the scholarship and the Max-Planck-Institut für Chemie for its hospitality and support. Reviews by A. Nédélec, S. Sindern. L. M. Larsen and T. Andersen led to significant improvements and clarification of some of the arguments presented in this paper.

\section{References}

Anderson, J.L., 1983. Proterozoic anorogenic granite plutonism of North America. In: Medaris, L.G., Byers, C.W., Mickelson, D.M. and Shanks, D.M., Editors, 1983. Proterozoic GeologyGeol. Soc. Am. Mem. vol. 161, pp. 133-153.

Anhaeusser, C.R., 1975. Precambrian tectonic environments. Annu. Rev. Earth Planet. Sci. 3, pp. 31-53.

Bailey, D.K., 1987. Mantle metasomatism; perspective and prospect. In: Fitton, J.G. and Upton, B.G.J., Editors, 1987. Alkaline Igneous RocksGeol. Soc. Spec. Publ. vol. 30, pp. 1-13. 
Blichert-Toft, J., Arndt, N.T. and Ludden, J.N., 1996. Precambrian alkaline magmatism. Lithos 37, pp. 97-111.

Bouhalier, H., Choukroune, P. and Ballèvre, M., 1993. Diapirism, bulk homogeneous shortering and transcurrent shearing in the Archean Dharwar craton in the Holenarsipur area, southern India. Precambrian Res. 63, pp. 43-58.

Brun, J.-P. and Pons, J., 1981. Patterns and interference between granite diapirism and regional deformation: abstract. J. Struct. Geol. 3, p. 93.

Cahen, L., Snelling, N.J., Delhal, J. and Vail, J.R., 1984. The Geochronology and Evolution of Africa, Clarendon Press, Oxford.

Choukroune, P., Ludden, J.N., Chardon, D., Calvert, A.J. and Bouhallier, H., 1995. Archean crustal growth and tectonic processes: a comparison of the Superior Province, Canada and Dharwar Craton, India. In: Burg, J.-P. and Ford, M., Editors, 1995. Orogeny Through TimeGeol. Soc. Spec. Publ. vol. 121, pp. 63-98.

Clemens, J.D., Holloway, J.R. and White, A.J.R., 1986. Origin of an A-type granite: experimental constraints. Am. Mineral. 71, pp. 317-324.

Collins, W.J., 1989. Polydiapirism of the Archean Mount Edgar Bathololith, Pilbara Block, Western Australia. Precambrian Res. 43, pp. 41-62.

Collins, W.J., Beams, S.D., White, A.J.R. and Chapppel, B.W., 1982. Nature and origin of Atype granites with particular reference to southeastern Australia. Contrib. Mineral. Petrol. 80, pp. 189-200.

Cox, K.G., Bell, J.D. and Pankhurst, R.J., 1979. The Interpretation of Igneous Rocks, George Allen \& Unwin, London, United Kingdom 445 pp..

Creaser, R.A., Price, R.C. and Wormald, R.J., 1991. A-type granites revisited: assessment of a residual-source model. Geology 19, pp. 163-166.

Delhal, J. and Ledent, L., 1975. Données géochronologiques sur le complexe calco-magnésien du Sud-Cameroun. Mus. R. Afr. Cent. (Belg.). Rapp. Annu. 1974, pp. 71-75.

DeWolf, C.P. and Mezger, K., 1994. Lead isotope analyses of leached feldspars: constraints on the early crustal evolution of the Grenville Orogen. Geochim. Cosmochim. Acta 58, pp. $5537-5550$.

Doe, B.R. and Zartmann, R.E., 1979. Pumbotectonics. In: Barnes, H., Editor, , 1979. Geochemistry of Hydrothermal Ore Deposits, Wiley, New York Chap. 2.

Downes, H., 1987. Tertiary and Quaternary volcanism in the Massif Central, France. In: Fitton, J.G. and Upton, B.G.J., Editors, 1987. Alkaline Igneous RocksGeol. Soc. Spec. Publ. vol. 30, pp. 517-530.

Drury, S.A., 1977. Structures induced by granite diapirs in the Archaean greenstone belt at Yellowknife, Canada; implications for Archaean geotectonics. J. Geol. 85, pp. 345-358. 
Eby, G.N., 1990. The A-type granitoids; a review of their occurrence and chemical characteristics and speculations on their petrogenesis. In: Woolley, A.R. and Ross, M., Editors, 1990. Alkaline Igneous Rocks and CarbonatitesLithos vol. 26, pp. 115-134. Abstract

Eby, G.N., 1992. Chemical subdivision of the A-type granitoids; petrogenetic and tectonic implications. Geology 20, pp. 641-644.

Edimo, A., 1985. Le massif syénitique d'Akongo-Lolodorf. Interprétation des anomalies radiométriques. Comparaison avec l'arc syénitique Mont des Eléphants-Rocher du Loup. Thèse 3 ème cycle, Univ. Orléans.

Fitton, J.G., 1987. The Cameroon Line, West Africa; a comparison between oceanic and continental alkaline volcanism. In: Fitton, J.G. and Upton, B.G.J., Editors, 1987. Alkaline Igneous RocksGeol. Soc. Spec. Publ. vol. 30, pp. 273-291.

Fitton, J.G. and Upton, B.G., 1987. In: Alkaline Igneous RocksGeol. Soc. Spec. Publ. vol. 30 568 pp..

Goldstein, S.L., O'Nions, R.K. and Hamilton, P.J., 1984. A Sm-Nd isotopic study of atmospheric dust and particulates from major river system. Earth Planet. Sci. Lett. 70, pp. 221-236.

Goodwin, A.M., 1991. Precambrian Geology, The Dynamic Evolution of the Continental Crust, Academic Press, San Diego 666 pp..

Harris, C., Marsh, J.S. and Milner, S.C., 1999. Petrology of the alkaline core of the Messum igneous complex, Namibia: evidence for the progressively decreasing effect of crustal contamination. J. Petrol. 40, pp. 1377-1397.

Harris, N.B.W., Duyverman, H.J. and Almond, D.C., 1983. The trace element and isotope geochemistry of the Sabaloka igneous complex, Sudan. J. Geol. Soc. (London) 140, pp. 245256.

Kober, B., 1986. Whole-grain evaporation for ${ }^{207} \mathrm{~Pb} /{ }^{206} \mathrm{~Pb}$-age-investigations on single zircons using a double-filament thermal ion source. Contrib. Mineral. Petrol. 93, pp. 482-490.

Kober, B., 1987. Single-zircon evaporation combined with $\mathrm{P}^{+}$emitter bedding for ${ }^{207} \mathrm{~Pb} /{ }^{206} \mathrm{~Pb}-$ age-investigations using thermal ion mass spectrometry, and implications to zirconology. Contrib. Mineral. Petrol. 96, pp. 63-71.

Kornprobst, J., Cantagrel, J.M., Fabries, M., Lasserre, M., Rollet, M. and Soba, D., 1976. Existence au Cameroun d'un magmatisme alcalin panafricain ou plus ancien: la syénite néphélinique de Nkonglong. Comparaison avec les roches alcalines connues dans la même région. Bull. Soc. Geol. Fr. 18, pp. 1295-1305.

Kröner, A. and Hegner, E., 1998. Geochemistry, single zircon ages and Sm-Nd systematics of granitoid rocks from the Góry Sowie (Owl) Mts., Polish West Sudetes: evidence for early Palaeozoic arc-related plutonism. J. Geol. Soc. (London) 155, pp. 711-724. 
Lasserre, M. and Soba, D., 1976. Age libérien des granodiorites et des gneiss à pyroxènes du Cameroun Méridional. Bull. BRGM 2 4, pp. 17-32.

Ludwig, K.R., 1999. In: Isoplot/Ex version 2.01Berkeley Geochronology Center Special Publication vol. 1a, Berkeley Geochronology Center, Berkeley, CA, USA.

Lugmair, G.W. and Marti, K., 1978. Lunar initial ${ }^{143} \mathrm{Nd} /{ }^{144} \mathrm{Nd}$ : differential evolution of the lunar crust and mantle. Earth Planet. Sci. Lett. 39, pp. 349-357.

Luhr, J.F., Carmichael, I.S.E. and Varekamp, J.C., 1984. The 1982 eruptions of El Chichon Volcano, Chiapas, Mexico; mineralogy and petrology of the anhydrite-bearing pumices. $J$. Volcanol. Geotherm. Res. 23, pp. 69-108.

Maurizot, P., Abessolo, A., Feybesse, J.L., Johan, V., Lecomte, P., 1985. Etude et prospection minière du Sud-Ouest Cameroun. Synthèse des travaux de 1978 à 1985. Rapp. BRGM 85, CMR 066, 274 pp.

Mezger, K. and Krogstad, E.J., 1997. Interpretation of discordant U-Pb zircon ages; an evaluation. J. Metamorph. Geol. 15, pp. 127-140.

Müller, D., Rock, N.M.S. and Groves, D.I., 1992. Geochemical discrimination between shoshonitic and potassic volcanic rocks in different tectonic settings: a pilot study. Mineral. Petrol. 46, pp. 259-289.

Nédélec, A., 1990. Late Calc-Alkaline Plutonism in the Archaean Ntem Unit; the Sangmelima granodioritic suite (South Cameroon). In: Rocci, G. and Deschamps, M., Editors, 1990. Etudes Récentes sur la Géologie de l'Afrique15th Coll. Afr. Geol. (Abs.), Publ. Occas. CIFEG vol. 22, pp. 25-28.

Nielsen, T.F.D., 1987. Tertiary alkaline magnetism in East Greenland; a review. In: Fitton, J.G. and Upton, B.G.J., Editors, 1987. Alkaline Igneous RocksGeol. Soc. Spec. Publ. vol. 30, pp. 489-515.

Nsifa, E.N., 1985. Analyse structurale de la région du Rocher du Loup (SW Cameroun). In: 110e Congrès National des Sociétés sav., Montpellier, Sciences, Fasc. VI, pp. 41-52.

Nsifa, E.N. and Riou, R., 1990. Post-Archaean migmatization in the charnockitic series of the Ntem complex, Congo craton, southern Cameroon. In: Rocci, G. and Deschamps, M., Editors, 1990. Etudes récentes sur la géologie de l'Afrique15th Coll. Afr. Geol.: Abstr., Publ. Occ. CIFEG vol. 22, pp. 33-36.

Nsifa, E.N., Tchameni, R. and Belinga, S.M.E., 1993. De l'existence de formation Catarchéennes dans le complexe cratonique du Ntem (Sud-Cameroun), Project No. 273. Archaean Cratonic Rocks of Africa: Abstr., p. 23.

Peccerillo, A. and Taylor, S.R., 1976. Geochemistry of Eocene calc-alkaline volcanic rocks from the Kastamonu area, northern Turkey. Contrib. Mineral. Petrol. 58, pp. 63-81. 
Schreurs, J., 1985. Prograde metamorphism of metapelites, garnet-biotite geothermometry and prograde changes of biotite chemistry in high-grade rocks of West Uusimaa, southwestern Finland. Lithos 18, pp. 69-82.

Smith, I.E.M., White, A.J.R., Chappell, B.W. and Eggleton, R.A., 1988. Fractionation in a zoned monzonite pluton: Mount Dromedary, southeastern Australia. Geol. Mag. 125, pp. $273-284$.

Steiger, R.H. and Jäger, E., 1977. Subcommission on geochronology: conventions of the use of decay constants in geo- and cosmochronology. Earth Planet. Sci. Lett. 36, pp. 359-362.

Stein, M. and Hofmann, A.W., 1994. Mantle plumes and episodic crustal growth. Nature 372, pp. 63-68.

Sun, S.S. and McDonough, W.F., 1989. Chemical and isotopic systematics of oceanic basalts: implications for mantle composition and processes. In: Saunders, A.D. and Norry, M.J., Editors, 1989. Magmatism in the Ocean BasinsGeol Soc. Spec. Publ. vol. 42, pp. 313-345.

Taylor, H.P., 1980. The effects of assimilation of country rocks by magmas on ${ }^{18} \mathrm{O} /{ }^{16} \mathrm{O}$ and ${ }^{87} \mathrm{Sr} /{ }^{86} \mathrm{Sr}$ systematics in igneous rocks. Earth Planet. Sci. Lett. 47, pp. 243-254.

Tchameni, R., 1989. Etude géologique et pétrographic du secteur NE de Mvengué (Sud Cameroun). Mémoire de Maîtrise Univ. Yaoundé, 78 pp.

Tchameni, R., 1997. Géochemie et géochronologie des formations de l'Archéen et de Paléoprotérozoique du Sud Cameroun (Groupe du Ntem, Craton du Congo). Thèse de Doctorat de l'Université d'Orléans, 395 pp.

Tchameni, R., Mezger, K. and Nsifa, E.N., 1995. Archean and Early Proterozoic evolution of the Congo craton (Southern Cameroon). EUG VIII, Terra Abstracts 7, p. 102.

Tchameni, R., Nsifa, E.N. and Mezger, K., 1998. Recyclage crustal à l'Archéen Supérieur dans le craton du Congo: Cas des granitoides potassiques d'Ebolowa, Groupe du Ntem. In: Vicat, J.P. and Bilong, P., Editors, 1998. Géosciences au Cameroun, Collect. GEOCAM, 1/1998, Press Univ. Yaoundé I, Yaoundé, pp. 339-350.

Tchameni, R., Mezger, K., Nsifa, N.E. and Pouclet, A., 2000. Late Archean crustal evolution in the Congo Craton: evidence from the K-rich granitoids of the Ntem Complex, Southern Cameroon. J. Afr. Earth Sci. Earth Sci. 30, pp. 133-147.

Teixeira, W., Carneiro, M.A., Noce, C.M., Machado, N., Sato, K. and Taylor, P.N., 1996. Pb, $\mathrm{Sr}$ and $\mathrm{Nd}$ isotope constraints on the Archaean evolution of gneissic-granitoid complexes in the southern Sao Francisco Craton, Brazil. Precambrian Res. 78, pp. 151-164.

Toteu, S.M., Van Schmus, W.R., Penaye, J. and Nyobe, J.B., 1994. U-Pb and Sm-Nd evidence for Eburnian and Pan-African high-grade metamorphism in cratonic rocks of southern Cameroon. Precambrian Res. 67, pp. 321-347. 
Turner, S.P., Foden, J.D. and Morrison, R.S., 1992. Derivation of some A-type magmas by fractionation of basaltic magma: an example from the Padthaway ridge, South Australia. Lithos 28, pp. 151-179.

Vicat, J.P., Leger, J.M., Nsifa, E., Piguet, P., Nzenti, J.P., Tchameni, R. and Pouclet, A., 1996. Distinction au sein du craton congolais du Sud-Ouest du Cameroun, de deux épisodes doléritiques initiant les cycless orogéniques éburnéen (Paléoprotérozoïque) et panafricain (Néoprotérozoïque). C.R. Acad. Sci. Paris 323 IIa, pp. 575-582.

Whalen, J.B., Currie, K.L. and Chappell, B.W., 1987. A-type granites: geochemical characteristics, discrimination and petrogenesis. Contrib. Mineral. Petrol. 95, pp. 407-419.

Whalen, J.B., Jenner, G.A., Longstaffe, F.J., Robert, F. and Gariépy, C., 1996. Geochemical and isotopic $(\mathrm{O} \mathrm{Nd}, \mathrm{Pb}$ and $\mathrm{Sr})$ constraints on $\mathrm{A}$ type granite petrogenesis based on the topsails igneous suite, Newfoundland Appalachians. J. Petrol. 37, pp. 1463-1489.

White, W.M. and Patchett, J., 1984. Hf-Nd-Sr isotopes and incompatible element abundances in island arcs; implications for magma origins and crust-mantle evolution. Earth Planet. Sci. Lett. 67, pp. 167-185.

Woolley, A.R. and Jones, G.C., 1987. The petrochemistry of the northern part of the Chilwa alkaline province, Malawi. In: Fitton, J.G. and Upton, G.J., Editors, 1987. Alkaline Igneous RocksGeol. Soc. Spec. Publ. vol. 30, pp. 335-355.

Zanvilevich, A.N., Litvinovsky, B.A., Wickham, S.M. and Bea, F., 1995. Genesis of alkaline and peralkaline syenite-granite series; the Kharitonovo Pluton (Transbaikalia, Russia). J. Geol. 103, pp. 127-145. 